\title{
The Investigation of Parents' Interactions and Their Children's Learning Levels at Parental Coaching Carried out over Social Network
}

\author{
Gülten Feryal Gündüz
}

700. yil Osmangazi Secondary School, Turkey

Copyright $\mathrm{C} 2018$ by authors, all rights reserved. Authors agree that this article remains permanently open access under the terms of the Creative Commons Attribution License 4.0 International License

\begin{abstract}
The study aims to provide academic and affective support for children's learning by using teacher-parent collaboration through parental coaching realized via social network. This parental coaching includes three phases: preparation, implementation and evaluation. The participants of the study are 16 parents and their children. The data of the study was obtained through the following data collection tools: family information form, focus group interview, semi-structured interviews conducted with parents and children, social network group logs, questionnaire and academic achievement scores of children. Descriptive analysis was used to analyze qualitative data and Wilcoxon $t$ test for quantitative data. The issues which the parents ask for support are guidance for supporting their children in the courses they have problems with and help children to develop reading and study habits. The findings of the study show that parental coaching via social network increases teacher-parent, parent-parent and parent-child interaction as well as children's academic achievement. The highest amount of interaction in this application was between parents and the guidance counsellor (the researcher) and the children. The lowest level of interaction was among parents. Finally, it can be concluded that parental coaching application helped parents to support their children's learning and feel well-equipped while guiding them.
\end{abstract}

Keywords Facebook Social Network, Parental Coaching, Parents, Technology, Teacher-Parent Collaboration

\section{Introduction}

Education is a lifelong process that affects cognitive, physical and personal developments of individuals as well as economic, social, cultural and political developments of the societies. Therefore, planning and designing an education system in accordance with modern developments to meet the needs of society and individuals are among the most important priorities of all the countries in the world [32]. According to Varış [82] education is the process of helping individuals to adapt to the society and its dynamics, enabling them to develop their skills to the highest level and helping them to acquire necessary behaviors to realize these functions. In the definition by Varış, social dynamics were considered as social and cultural institutions, facts and values that affect the society [55]. According to the literature, the requirements of the $21^{\text {st }}$ century individual skills include critical thinking, problem solving, cognitive skills, creativity and entrepreneurial thinking, communicating and collaborating, making innovative use of knowledge, information and opportunities and taking charge of financial, health and civic responsibilities [56]. In order to talk about realistic education and achievement of its goals, it is necessary for the individuals to demonstrate the related competences in their behavior and their knowledge on these competencies could be observed. Education process is mainly based on learning. Learning process begins in the family with the birth of a child and continues at the school, which is an institution operating on well-planned and programmed principles. School administration and teachers are responsible for the planning and implementation of teaching activities at school. Developments in science and technology have not only created changes in the structure and the processes of education but also brought about some changes in the roles and teaching practices of teachers. Calderhead [11] explains the rapidly changing role of teachers as follows: "It is necessary for a teacher to coalesce with students, to understand their feelings, to organize the teaching environment and to communicate with colleagues and parents regularly. Biller [9], who emphasizes the importance of teachers' having good relationship with families, suggests the following: "A 
teacher should visit families and even s/he should invite them to the class, be interested in their personal problems and ask for their support to get to know his/her students better.." [9].Parents and teachers should work together to create a suitable learning environment for students. It is acknowledged that the first learning experiences of a child at home enhance the possibility of his/her success in in-class activities. Therefore, it is important for teachers to observe the family environment of the child and to have contacts with family members to guarantee better educational practices (Burns, Roe \& Ross, 1992 cited by [12]. If the ultimate goal is to provide students with quality education and prepare them for life, it is impossible to exclude families who try to do their best for the success of their children from this process [30]. School, students, teachers, administration, parents, immediate environment and non-governmental organizations related to education interact with each other in a collaborative way. School and parents should complement each other and behave consistently for the socialization of students in order to achieve the predetermined objectives of the school [46].

\subsection{Parental Involvement in the Process of Education}

Parental involvement is defined in numerous ways, ranging from parental aspiration, expectation, interest, and attitudes and beliefs regarding education to more active parental participation and practice in specific activities at home or school [4]. In a very general sense, Green et al (2007) stated that parents who are active participants in their child's education are thought to promote children's social, emotional, and academic development [61]. In a different dimension, parental involvement concerns a wide range of issues, such as parental expectations about their children's academic future, control over homework, the extent to which they become involved in helping children to learn for school assignments or to do the homework, or the frequency with which parents are physically present at school [61]. According to Hatos (2004) parental involvement is the totality of strategies, actions and resources, which the parents use during the tuition of their children in order to improve their chances to become successful from an educational and social point of view [58].

As it can be seen from the definitions, parental involvement as a concept involves a large number of parental behaviors that affect academic success and cognitive development of students directly or indirectly. In this respect, educators and researchers worked on different classifications related to the types of parental involvement. Lawson [52] suggests four different types of participation, which are "structuring the educational environment for the child at home, helping paper work at school, participating in child development activities as well as cultural and extracurricular activities; helping the teacher like an assistant during lessons; being a part of parent-teacher associations as well as decision making commissions at school; solving problems at school; helping the arrangements made at school, assessing and applying restructuring strategies and reforms of school as the close partners of school administration. Swap (1993) uses four models to explain parental involvement in education process and to describe the relationships between school, family and society. These models are "protective model", "home-school communication model", "curriculum development model" and "collaboration model". In protective model, school is responsible for the education of students and uses ceremonies and structures to eliminate the possible intervention of the families. Families have their own responsibilities at home and teachers assume all kinds of responsibilities of students in school environments. In home-school communication model, teachers prepare and organize all kinds of activities that families can do to support the learning of students. In this model, parental involvement occurs only if the school needs anything and asks for help. Curriculum development model is about collaboration between families and educators, and objectives are determined collaboratively. Here relationships are limited to the curriculum; they are not extended to school administration or policymaking issues. In collaboration model, processes that require collaboration between educators and families to solve problems and to provide support for the success of the school are used [81].

Epstein [22] examines parental involvement process in six different categories; namely training, communication, voluntariness, learning at home, decision-making and collaboration with society. The responsibilities and duties of schools to ensure parental involvement are stated in each of these categories separately. Accordingly, Epstein [23] emphasizes that teachers should support families in terms of health, food and educational activities according to their children's learning levels and ages. As for communication purposes, it is highlighted that effective communication channels should be established between school and home, and meetings should be organized with parents, and the monthly and weekly reports about students should be sent to families. The third category gives importance to develop activities and programs to encourage volunteer families to take part in. For decision-making category, it is essential to include families to the decisions taken at schools through parent-teacher associations and other family organizations. "Learning at home" category covers informing families about how to help students for their homework, course activities and lesson plans. "Collaboration with society" category is about the coordination of the attempts by social groups such as associations, universities, business enterprises etc. and the sources that help students' learning and developments. According to Keith, Keith, Kimberly, Sperduto, Santillo and Killings [47], the studies conducted defines "parental involvement" under four categories: parents' expectations from the child with regard to school 
life; communication between school, family and student; participation of the parents in school activities and learning activities.

As it can be understood from the explanations and classifications made by educators and researchers, the responsibilities of families regarding involvement in education process can be discussed from a wide range of perspectives. Under the light of the explanations made, parental involvement in education process can be summarized under the following subtitles: supporting out of class (home) education, participation in classroom and whole school activities; and having a say in the decision making process regarding school programs, school rules and activities.

\subsection{The Importance of Parental Involvement in Education Process}

According to Hester [34], parental involvement and effective schools cannot be considered independently from each other. Family is the smallest social unit of society and parents are the very first and natural teachers of children since a child acquires first educational experiences about feelings, behaviors, and thoughts in family environment. These experiences form a basis for child's cultural and educational identity. According to Gordon [28] family affects the child to a great extent. To illustrate with, when children are between 0-6 age period, parents are the closest people to them and they meet all their needs and they are their first teachers. When the fact that personality development start in 0-6 age range is considered, the importance of parents in the development of educational identity can be understood better. Although this teaching role passes to teachers when a child starts school, the role of parents in their children's education continues. When a child starts primary school, environmental factors affecting academic achievement extend to wider sections of society; however, the effect of family does not completely end. When the time spent at school in a day of 24 hours is considered, it is clear that $3 / 4$ of a child's time is spent with the family. This situation clearly shows the significance of family-child interaction. Carneiro [12] states that child spends only a certain amount of his time at school, and he spends the rest of his time with his family and his social environment. As a result, students' academic achievement is mainly explained by the characteristics of the family. When the related literature is examined, it can also be seen that there are many studies which conclude that parental involvement in education increases academic achievement $[6,14,35,43,48,52,62,63,68]$, and decreases the number of disruptive behaviors and discipline problems [6, 14, 27, 29, 35, 44, 49, 64, 83]. Although numerous researchers (Domina 2005; Stein and Thorkildsen 1999; Zellman and Waterman 1998) have focused on variation in parental involvement in children's education [61], scholars still disagree about how parents should be involved and which aspects of parental involvement are associated with improvements in children's academic outcomes. Teachers also have some concerns about educational practices carried out in out-of-school environments. Teachers want to find answers to the following questions: "What kind of educational environment is the child experiencing? What kind of help do parents provide for their children with their homework?, Do families criticize schools and teachers?, Do parents care about their children's problems about school and lessons?" [28].

\subsection{Recent Studies Conducted on Parental Involvement}

It can be said that parental involvement in education process has recently been one of the most important concerns of each country all over the world. Although researches about parental involvement are extensively conducted in the United States and European countries, parental involvement studies done in Eastern countries are increased day by day. Parental involvement and parent-teacher association differs across cultures especially between eastern and western countries. It is difficult to determine common policies on the methodology of parental involvement in eastern countries in contrast to the European Union nations. Although the significance of parental involvement is emphasized in most eastern countries, there are differences between the national practices. In certain Eastern countries, parental involvement in their children's education is mostly home-based involvement rather than the school-based environment, and parents are not involved in decision-making processes on the duties of the school, curricula and practices. Chinese teachers do not believe that parents should be involved in the decision-making process, but they do wish to inform and consult parents about students' learning in order for them to assist learning [51]. Huntsinger and Jose [40] stated that in Asian cultures there is a clear separation between parents and teachers. In Hong Kong, their overlapping area was described as "nearly zero." Parents are very involved with children's learning at home, but not at school. In their study conducted with Chinese (CA) and European American (EA) parents, they found that immigrant CA parents were more highly involved with their children around academics at home and that EA parents participated to a greater extent in activities at school. In the related literature, the researches revealed that it is not only true for immigrant Chinese parents, but also Chinese parents living in mainland China [40]. Lau, Li and Rao [51] explored the pattern of parental involvement in the Chinese context. They used early parental involvement scale for obtaining data. The scale covers six parental involvement dimensions named Parent Instruction, Homework Involvement, Home-school Conferencing, Language and Cognitive Activities, Parent Discussion and School Involvement. They found that the 
Chinese parents practised more home-based involvement than school-based involvement during the early years. In particular, Home-school Conferencing and School Involvement only ranked the third highest and the last among the six parental involvement dimensions, respectively [51]. Ho [36] also stated that in the Chinese context that home-based involvement is strongly encouraged, whereas school-based involvement is not so welcome and categorized parental involvement in the Chinese culture into four types: home discussion, home supervision, school communication and school participation. The main difference of Ho's model from the other parental involvement models used extensively in western contexts is the lack of decision-making dimension. In the case of Cyprus, parental involvement is similar to China. Symeou [66] stated that home-school links are extremely limited in Cyprus. The range and nature of such bonds in Cyprus seem to depend on how open the schools are towards parents and from the initiative exhibited by the parents as individuals [66]. In his research, Symeou [67] found that the current practices employed by primary schools in view of involving the parents of the pupils in their school life are focused on projecting to parents the work done at the school. Such practices are sending informative letters to parents, inviting parents to watch a lesson in their children's class, and organizing feasts and events addressed to parents. However, practices which aim at educating parents in pedagogical and educational subjects, what was called 'Parental training' practices are rarely practiced. Similarly, practices, like inviting parents to organized class or school activities and events where the assumptions is that parents could offer their insight and expertise or parents should be allowed to share with the educationalists some school instances were found to be rarely established [67]. In countries where parents are not effective on the decision-making processes at school such as China and Cyprus, the achievement of desired level of teacher-parent association, which is significant in parental involvement, becomes difficult.

In a large majority of eastern countries, the model of parental involvement is based on the internationally accepted dimensions of Eipstein (1995) model, which has been implemented by several countries. Some of these countries experience difficulties in implementing the model although they take the dimensions of parenting named as communication, parents' volunteering, learning at home, decision-making and collaborating into account. Syamsudduha and Ginanto [66] examine the role of parental involvement in two public schools in Makassar utilizing Epstein's parental involvement framework. They conducted a focus group discussion (FGD) over school principals, teachers, and parents. They also conducted observations towards parental involvement activities in both schools. They found that parenting, communication, collaborating and parents volunteering have not been optimally performed. Home visit programs for parenting are only undertaken when learner are in problem. Communication between parents and school is held formally and the material discussed is generally related to academic achievement and slightly other aspects such as child health and behaviors except for children who have special records from counseling teachers or troubled children. The same is valid for Iraqi and Syrian families. In a report published in 2009 by UNICEF, it was demonstrated that most Iraqi and Syrian families visit the school only when there are problems at school with their child [80]. However, in Indonesia learning at home and decision making in parental involvement are implemented more effective that other dimensions. In the aspect of home studying assistance, parents have been adequately involved through several activities undertaken by teachers and schools. Parent involvement in decision-making is important in Indonesia. With regard to decision-making, parents are involved in fund-raising matters or creating work programs concerned on school development such as procurement of learning support facilities and extracurricular activities. It is also possible to refer to eastern countries that were able to apply parental involvement effectively in their educational systems. It was observed that these countries also have higher academic performance in international examinations. In Japan, communication with parents is conducted through several channels, including a short home visit by the teacher at the beginning of the school year, one or more observation days in which parents are able to witness a typical school day, regularly scheduled parent-teacher conferences, and the use of a notebook that teachers and parents pass back and forth to exchange comments about student progress [37]. Jabar [42] states that Japanese parents are audience, volunteers, paraprofessionals, teachers, learners, decision-makers, and parents as partners of teachers and other parents. In Japanese school, the school orientation provides them with information about school norms and policies. Another school activity is open school, which is usually being held at the beginning of the school year. Parents sit in on a class and listen to the teacher's lecture. Schools in Japan also provide venues where parents can participate as volunteers. Parents were asked to fill up a volunteer form indicating their interests, expertise, and experiences. The information gathered is used to create a "talent bank" or database containing parents' names and expertise, which the school refers to when it needs the services of some parents. Japanese schools also encourage parents to act as paraprofessionals. Parents in elementary schools take turns in safeguarding school children on the road. During summer break parents are expected to act as teachers of their own children. They are expected to help their children accomplish their summer homework. Schools in Japan also offer activities for parents. As learners, parents are provided with seminars to improve their own efficacy in educating and rearing their children. Parents in Japanese schools play pivotal role in 
parent-teacher associations. As decision makers, parents more than teachers make decisions about the affairs of the association. These roles suggest of an "active" partnership between parents and teachers and among parents through open communication. The role of parents as teacher's partners in educating children is particularly evident in Japanese schools because of the open and available communication channels between teachers and parents. The other role of parents as partners of other parents may be seen in the contact network. The contact network is used when the schools need to convey information to parents regarding school-related matters over the phone. Children association, a community-based group consisting of school children and parents, is another avenue where parents can interact and exchange ideas pertaining to their children's education.

The studies conducted by the World Bank or the European Union in collaboration with governmental and non-governmental organizations on parental involvement in the Middle East and Far East countries demonstrated that parental involvement is limited with the meetings between the parent and the teacher of the student in most of these countries, particularly in the case of Eastern countries with low socio-economic level and schooling rate. These meetings are mostly related to the problem in academic performance or undesired behavior of the child $[66,80]$. In eastern countries with high socio-economic level and schooling rate, the parental involvement is usually in the form of both home-based involvement and school-based involvement. In these countries, the academic performance of children is highly regarded by their families, and thus, supporting their children's learning at home is also very important for them.

In the studies conducted on parental involvement in education process in Turkey, educational policies of European Union and educational objectives of Turkey's development plans are considered effective factors. Although European Union countries are independent in terms of using education models that are appropriate for their own socio-economic structure, the Union determined certain common principles that are required to be applied in national education systems. European Council, which met in Barcelona in 2002, emphasized the importance of Lisbon process and agreed on the following strategic goal "making Europe the world leader in education and teaching practices by $2010 "$ " [71]. In order to achieve its strategical goals, European Union determined 4 fields and 16 principles to evaluate quality in education. One of these principles under the field "monitoring education process" is parental involvement in education process. According to this principle, European Union countries agree on the following issues regarding family-school collaboration: legal counseling and decision making; evaluating school systems; voluntary partnerships; voluntary participation in out-of-school activities or clubs; voluntary participation in in-class-activities; and collaboration with schools in terms of supporting their children's learning [32]. The learning outcomes determined in Education and Teaching 2010 Study Program were revised and updated to Education and Teaching 2020 Study Program [77]. Developed within the scope of both European Union education policies and $10^{\text {th }}$ Development Plan, family protection policy aims to eliminate the deficiencies in family education, train qualified individuals, give an end to the lack of communication among family members; and prevent domestic violence, negligence and abuse [78]. In addition, Country Action Plan (2011-2015) signed between Turkish government and UNICEF suggests the realization and implementation of Early Childhood Development, Strengthening of Youth, and Effective Parenting. Turkish Ministry of National Education arranged Family Training Course Programs (for 0-18 age group) by taking family education as the priority area of prevalent education activities in order to strengthen social development and prosperity. The programs that have been implemented are Family Education Course Program for age groups 0-3, 3-6, 7-11, 12-18; Family Development Course Program for age group 3-6; Father Support Course Program for age group 3-6 and of Support Training for Illiterate Mothers Course Program for age group 3-6 [79]. These family training attempts are designed and implemented within the framework of mass education activities under the supervision of Turkish Ministry of National Education in Public Education Centers, and they aim to serve especially to the children of families who have low socio-economic background and are under risk.

Thanks to new education and teaching programs initiated in 2005-2006 academic year in Turkey aim to increase involvement of primary and secondary school student's parents in education process and to make this involvement more effective. In addition, these programs aim to make parents important stakeholders of teaching and learning through out-of-school activities and make it easier for parents to monitor the development of their children thanks to assessment and evaluation tools applied in the programs [71]. The Ministry of National Education prepared "Primary School Parents' Guide for an Effective Understanding of Students and the Program" in 2008 in order to inform parents about parental involvement and increase their awareness [72]. This guide included suggestions regarding how school learning and content can be supported by the families at home for 1-8 grade students in the following courses: Turkish, Mathematics, Life Sciences, Social Sciences and Science and Technology. The responsibilities of teachers to inform families and increase their awareness of families while encouraging their effective involvement in their children's education were also given importance, and certain steps were taken accordingly. In 2006, The Ministry of National Education Teacher Training and Education General Directorate defined "Qualifications of Teaching Profession" within the framework of Support for Basic Education Project [73] 
One of these qualifications was determined as "Ensuring Parental Involvement and Collaboration", and it is highlighted that each teacher should encourage and motivate families to contribute to teaching-learning process and help families to trust school system. In addition, it has been emphasized that teachers should establish collaboration with families by regularly informing them about the developments of their children.

In Turkey, parental involvement in education is regulated by Parent-Teacher Association Regulations. The responsibilities of Parent-Teacher Associations, which are established in accordance with this regulation, are to provide a sort of unity between school and families, to ensure collaboration between parents and teachers, to support activities that improve education and learning, to meet the needs of poor students, and to provide financial support for the school [74]. It is no doubt that teachers have important roles in the effectiveness of the attempts initiated to increase parental involvement. The studies focusing on school-family and teacher-parent collaboration clearly reveal that schools are not successful enough in establishing effective collaboration [3, 19, 85]. This collaboration was found to be limited to parent-teachers meetings held once or twice in an academic year, donations made to school by parents, and parents' visit to school to get information about their children's performances in lessons or when a problem occurs $[8,15,24]$. In fact, the definitions of parental involvement involve a large number of family behaviors affecting cognitive development, school achievement and motivation of children and their attitude toward learning. In this respect, the communication of teachers with parents should not be limited to families' financial support for school, visits to school only when a problem occurs or taking part in organizational activities at school. Teachers should guide parents in how they can support their children's academic developments out-of-school as well. Unfortunately, the findings of some studies focusing on teacher-parent collaboration reveal that such collaboration cannot be established somehow. The possible reasons of this situation can be stated as follows: Not having planned and purposeful meetings with parents; or not having efficient and functional meetings when they are held [19]; lack of documents and channels by parent-teacher associations to inform parents about how to initiate and improve educational process [3]; the negative effect of low-level socio-cultural background of parents on information provision $[3,85]$; teachers' not having adequate training about parental behaviors during pre-service and in-service training programs and their not showing enough enthusiasm to improve themselves in this issue [30].

\subsection{Recent Studies in Parental Involvement via Social Media}

The problems encountered regarding the parental involvement result in not having a desired level of teacher-parent collaboration and not being able to initiate innovative applications in the field. Although the importance of teacher-parent collaboration and parental involvement in child's education process are emphasized in the literature, not being able to establish efficient and quality teacher-parent collaboration is considered a serious problem.

As stated by Şahin and Ünver (2005), it is necessary to adopt an approach that unites and relates family education and school, which provides systematic and organizational education, so that it might be possible to encourage families to support and contribute to their children's education [24]. Research has identified barriers that prohibit parents from being involved in their children's education, including having work commitments, not knowing how to help their child, not feeling welcomed at the school, inability to understand the educational process, and lack of time due to their day-to-day responsibilities (Davies, Henderson, Johnson, \& Mapp, 2007; Hall et al., 2005 cited in 55, 17). Olmstead [55] stated that as working parents are finding it harder to be involved in their children's academics, schools need to start using electronic means to communicate with parents. These can include various kinds of technology as voice-calling systems, videos, media, websites, instant messaging, text messaging, email, parent portals, and weblogs. Tubbs and Moss (2006) stated, "communication is effective when the stimulus as initiated and intended by the sender, or source, corresponds closely to the stimulus as it is perceived and responded to by the receiver". Similarly, Hagel and Brown (2005) found that many schools push information to parents but, they do not provide any means for parents to share information. They suggest that schools need to enable parents to pull information when needed and communicate with the school when needed. Technology allows for this type of communication [55]. The most recent tool used by school to communicate with parents and to remove the limitations due to space and time is social media.

By using social media, schools can improve current marketing and community outreach plans. Social media can help schools celebrate activities and accomplishments. When schools use social media they are also fostering constructive dialogue with community members. Social media also provides schools with the opportunity to communicate in a manner similar to how most parents, organizations, companies, and communities are already utilizing; social media can promote interconnectedness and community involvement and engagement [33]. Social media provide a great way for schools to build on this familiarity, and engage parents in learning the skills that will boost student success. Schools can provide online informational "classes" on subjects for parent-teacher conferences. After posting videos to a social media site such as YouTube, schools can promote them to parents by 
posting links on Facebook or the school website. Social media can also be used to create groups for discussion forums between parents and teachers or administrators [75] It can be said that the most social media tools used in parental involvement are blogs, web sites and social networks

Blogs offer anyone with Internet access to post his or her writings and allow for reader comments. The newer and more interactive form of blogs are called wikis, which are web applications that allow users to write content but that allow anyone to edit the content by adding to or modifying the existing text. For example, a parent could set up a wiki in advance of an international-theme potluck lunch, whereby parents can post their expected contributions and see what other parents are bringing [55]. Baskwill [7] stated that a blog attracts parents' attention. Having a blog that talks about teaching and learning, with the aim of sharing knowledge with parents, is a great way for teacher to help parents deal with issues that affect their children and to support them by helping them support their children's learning. They are also added that a blog lets parents see that teachers are people. Parents appreciate getting to know their child's teacher as a person. It helps to build rapport and establish a closer relationship.

The other social media tool used in parental involvement is websites. They can be the school's websites or individual teacher's websites. School Web sites are used to convey abroad range of school information. Teachers trained to use the school Web site can provide updates easily accessed by parents regarding homework assignments, test schedules, resource links, and so on [31]. Teacher websites provide parents with homework assignments and class news. Teacher Ms. Glass, who was the participant of the study conducted by Curtiss, Pearson, Akamoglu, Fisher, Snodgrass, Meyer, Meadan and Hall [18] explained how she actively used the class website in parent-teacher collaboration. Ms. Glass linked to the iPiCS program and some of her own materials on her class web site. She said that the class web site would be a great space to teach parents, about the communication strategies she used in the classroom and how they could be used at home. She stated that she used some of her professional development time to set up the web site and had allocated weekly parent contact time into her preparation periods. She expressed that she checked her web site and even had colleagues reviewed it to find links that did not work and forms that did not download. If there was a problem, she reorganized her materials to maximize adult learning and corrected these problems before introducing it to parents. To establish rapport, she sent a carefully worded e-mail to a couple of parents, briefly explaining how they could work on expressive communication at home and providing them with a link to the class web site. As parents completed each module, she gave them feedback on the materials they uploaded. If parents did not work on the modules for 2 weeks, she sent them an e-mail reminder. After Ms. Glass had launched her web site with all of the parents, she used a short survey to obtain feedback from parents on whether or not they liked the program. She also learned that her class web site had a tool allowing her to see how often the links were clicked on and how often materials were downloaded. She used these tools to evaluate her efforts. The parents trusted she was making every effort to build a collaborative relationship and were excited to see their children's communication gains that they had heard about at school. In contrast, according to the results of Olmstead's [55] research, parents who participated in semi-structured interviews noted that several teachers do not update or provide enough information on their websites for the information to be useful but that the school website is always updated. In the semi-structured interviews, teachers stated that keeping their websites updated was time consuming. Due to these problems, more parents stated that they checked the school website than the teachers' website on a regular basis. Although many schools have websites, parent, teacher, and principal perceptions about the use of these websites for communication differ. Bouffard [10] found that only $36 \%$ of families indicated that teachers use the Internet to communicate with them, even though $60 \%$ of principals reported that teachers use the Internet in this way. Olmstead [55] stated that this discrepancy may lie in the difference between pushing information out to parents and allowing parents to pull the information that they need.

Social networking has an important potential in the field of education due to interaction and communication tools they have and their popularity. Social networking can be useful as a tool for collaborative planning, sharing resources, providing news and updates to pupils and parents, helping with homework and project assignments, promoting school and class achievement, recording and archiving lesson content for revision and keeping up to date with the latest pedagogy. The format also appeals to students and is easy to access for parents and teachers [25]. One important step to enhance parental involvement is to take part in the parent's environments and reach them through the communication channels used by the parents. Most parents actively use social networks for different reasons such as searching for employment, sharing content with friends and relatives and finding information. Duggan, Lenhart, Lampe and Ellison [21] conducted a study to explore how parents turn to social media for parenting-related information and social support. The participants of the study are 1235 social-media user and 241 of the participants are parents with children under 18 . The results indicated that social media is broadly viewed as a source of useful information and as one parenting tool among a collection of options by parents. Mothers use it as a parenting resource slightly more often than fathers. This survey also took a broad look at the social media habits of parents. Three-quarters of online parents use Facebook, 28\% of online parents use Pinterest, $27 \%$ of online parents use 
LinkedIn. $25 \%$ of online parents are Instagram users and 23\% of online parents use Twitter. According to these results, it can be said that the most used social media by parents are facebook and pinterest. Considering the social networks used by parents, it could be argued that utilization of Facebook and Twitter social networks are more effective in providing parental involvement when compared to the above mentioned social networks. This is mostly due to the fact that these social networks are frequently used by parents, enabling the sharing of different types of information such as pictures, videos and text, and their ability to promote teacher-parent interaction and communications more effectively and efficiently when compared to other social networks via the posts. Many parents are already on Facebook, so it makes sense to communicate with them on a platform with which they are already familiar. Facebook allows teachers to share class news and information with the parents of their students. Types of information teacher might share: details of upcoming field trips, school closings (scheduled or unforeseen), special events or parties, pictures of student projects, students' published writing, etc. Facebook has a feature that allows teacher to post updates that parents will see immediately when they log onto their page. Parents can also send teacher a private message to ask questions about homework or to ask for a meeting. Twitter is another platform with which many parents have experience - or about which they are eager to learn. Twitter is a communication tool in which information is communicated in short posts of up to 140 characters (called Tweets). It is also possible to post links, photos, and videos. Twitter can be used to post reminders about events, share news of the day and share photographs and information from school-wide activities and class trips [7].

The related literature $[16,33,55,18]$ has demonstrated that the use of social networks in parental involvement mostly entailed the use of school Facebook page or Twitter account and information posted on these platforms. Hernandez-Cruz and Russel's [33] study revealed that the school's Facebook page or twitter account increase the parent involvement, parents know what is going on in the school and teachers provide parents useful information about student learning. Chairatchatakul, Jantaburom and Kanarkard [16] examined how school use Facebook to engage parents, foster relationship growth in parent-school and also to learn which school information the parents preferred in their study. The usage and application of the school Facebook Page in several features namely, presence of school information, questions, interesting links, events, places and photo and video albums. In addition to displaying student work, the school can present the students works to all parents. Parents may not come to school, but many are happy to come to see their students' work displayed in the school Facebook. They can also provide their feedbacks on school policy summarizes the demographic profile of parents including their age, gender, and language and place of use. This information helps school to understand who school parents is and who includes parents liking school Page, liked, commenting on or sharing a post from school Page, answered a Question asked on school Page, or tagged school Page in a photo or in a status update [16]. Hernandez-Cruz and Russel [33] conducted a study consisted of measuring current social media practices especially Facebook and Twitter, a survey distributed to school and district leadership, and a statistical analysis regarding community involvement and social media use. They also researched how social media influence parental involvement. The survey revealed that most of the principals agree that schools should do more to engage with students and parents on social media platforms. They believe to be the most relevant information to share via social networks is school events, schedule changes, student work, administrative change and extracurricular activities. Based on the study findings, it could be stated that the posts on school Facebook page or Twitter account that aimed parental involvement mostly included promotional content such as information on the school profile, school activities, photographs and videos of these activities and school program rather than providing guidance on the parental support that could improve the children's learning. Based on the literature, it can be stated that there are only a few studies that investigated how social networks can be used to guide families on supporting the learning of their children. However, in his study, Olmstead [55] concluded that although teachers did not use social networking tools such as Twitter or Facebook to communicate with parents, most of them said that they were willing to use these tools for parent communication. The reasons why most of teachers don't use social networking in parental education include multiple factors such as lack of training for teachers in how to use technology to increase communication with parents or lack of research in this area because these types of technologies are relatively new in the field of education. However, many sources for support exist for how social networking can be used in parental education. They are including websites such as "Edutopia" (www.edutopia.org), "Common Sense Media" (www.commonsensemedia.org) and classdojo, which provide information, reviews, guides and toolkits, can empower parents and educators to foster safe and productive use of digital resources by children and adolescents [56]. Although no studies were found in the literature on the training of parents about the support of the education of their children in using social networks, there are studies utilized various educational software that could be used in family education. The Internet-Based Parent-Implemented Communication Strategies (iPiCS) was developed by Meadan, Meyer, Nodgrass and Helle (2013) [cited in 18] and it was tested for its impacts [18]. It could be stated that this software is similar to the use of 
social networks in family education based on the utilized online technologies, learning environment and instructional tools.

The iPiCS program is an online training and coaching program for teaching parents naturalistic strategies to enhance the support for young children with very limited expressive communication. The iPiCS program utilizes online modules and videoconferencing to teach and coach parents on how to use environmental arrangement, modeling, mand-model, and time delay. Environmental arrangement refers to structuring the home to enhance communication opportunities. Modeling refers to displaying the communication the parent wants the child to use, and mand-model refers to using a verbal prompt to elicit communication. Time delay is a strategy for structuring opportunities to respond or initiate by pausing. Four questions were considered in the application of the program. These are; what content should parents learn? How should this information be taught? How will technology be used to reach parents? And how will parents' progress toward program goals be measured? The content of the online family education program will vary based on the individual needs of the students the practitioner is targeting. Having determined the content to be covered, the next step is to determine how this content will be taught. First, arranging frequent communication channels (e.g., weekly via e-mails or videoconferencing) to correspond with families can ensure regular opportunities for parents to discuss their questions and concerns. Second, there are many ways practitioners can express their commitment when providing education online, including responding quickly to parents' e-mails or questions and addressing technical problems as they arise. When preparing for program implementation, it is important to identify the online learning platform. In evaluation, they stated that practitioners should ask questions about parents' feelings regarding (a) the educational content (i.e., goals), (b) the methods used to teach the content (i.e., procedures), and (c) the impact or success of the training (i.e., outcomes). Besides, online platforms offer options for collecting and analyzing relevant data on usage. For example, many learning platforms can provide data on how often each video was viewed, how much time parents spent viewing material, and how many times they clicked on links to view specific content [18].

As it can be seen in the related literature, parental involvement can be fostered through the use of social media especially social networking. Although there are studies focusing on the effectiveness of the social networking in the education and data revealed that both parents and teachers perceived that social networking is also an effective tool to promote parental involvement no studies have been conducted yet focusing on how parents of secondary school students can use social network in supporting their children's learning.

\subsection{The Aim of the Study}

This study aims to define how parental coaching can be realized via social network in order to help parents to support their children's learning out of school. In addition, the effects of parental coaching application on parents and students were also examined according to some variables. The study looks for answers to the following questions to achieve the aims stated above:

1. How can an educational application be designed to help $5^{\text {th }}$ grade secondary school students' parents to support their children's learning via social network?

2. What is the pattern of interaction between parents and classroom guidance counselor in parental coaching carried out via social network?

3. What is the pattern of parent-parent interaction in parental coaching carried out via social network?

4. What is the pattern of parent-child interaction in parental coaching carried out via social network?

5. What are the problems encountered during the preparation and implementation of parental coaching via social network?

6. What are the benefits of parental coaching carried out via social network for $5^{\text {th }}$ grade secondary school students' parents?

7. How do the $5^{\text {th }}$ grade secondary school students' learning levels change after parental coaching carried out via social network?

\section{Materials and Methods}

This section includes information about the research model, study group, data collection tool and analysis of data in the study.

\subsection{Research Model}

Using case study model, this study aims to define how parental coaching realized through social networks can be organized in order to help parents support their children's learning out of school. It also aims to examine patterns of interaction with parents and the changes at students' learning levels. Yin [86] suggests that case study is an in-depth investigation focusing on actual phenomena, event, case, situation or groups. According to Yin [86], case studies in the field of education are often preferred to answer "why" and "how" questions. In addition to these questions, case studies are also important in answering "what" questions [85].

According to Yin [86], case studies are carried out in four different ways: holistic single case embedded single case, holistic multiple cases and embedded multiple cases. This study uses holistic single case design, in which there is only one analysis unit such as an individual, an organization, a program and a school. Holistic single case 
studies is preferred - if there is a well-established hypothesis to be verified or confuted - when unique, extraordinary, extreme and conflicting cases are present or there are not many studies conducted on this specific issue. Many studies have been conducted so far about the use of Facebook social network in the field of education; however, since its use with parents while supplementing their children's learning has not been the topic of any research so far and it is a single issue that needs to be examined in detail, this study uses holistic single case study design.

\subsection{Facebook Social Network}

The analysis unit of this case study is social network group created through Facebook. Facebook is social network website, which enable users to connect, join groups and share resources through private or public messages at various levels of accessibility [76]. The use of Facebook social network in educational contexts is known to provide considerable benefits for students and teachers. It is possible for teachers and students to create an educational group, share content among themselves and communicate and receive feedback through social networks only by following certain easy steps. In addition, social networks provide extra advantages such as supplementing learning and teaching process by enriching the process through texts, videos and audios [59].

Different communication channels can be used to ensure parental involvement in education process. Among these methods of communication are letters sent to parents about the activities at school, the leaflets providing information about school rules, school system and other information that parents might need, the personal reports about students, telephone calls between teachers and parents, family visits during which teacher can give information about the student or learn more about him / her, and organizing in-class activities watching days so that parents can watch their children's activities [Burns et al., 1992 cited in 13]. In addition to these communication channels, more tools such as e-mail, teleconferencing and facsimile can be used to communicate with parents thanks to technological developments [13].

Considering the advantages provided by Facebook for two important components of education - learner and teacher-, the researcher thought that it can also be used to support children's learning by establishing effective communication and interaction between teachers and parents. The reasons for preferring Facebook to create an interaction and collaboration between teachers and parents in this study are as follows: it does not require too much background information about the system [45]; it makes it possible to share educational materials by using audio-visual multimedia environments; it is possible to create groups, publicize activities and do announcements, to add or remove users from groups, to set closed groups; and it is possible to access other educational software easily and quickly. Considering these advantages, a Facebook group was created, which was titled "Eğitim Geliştirme Çalışmaları (Education Development Studies)". The members of the group are the researcher, who is also the guidance counsellor of the class, and the volunteer parents who want to join the group.

\subsection{The Participants of the Study}

The participants of the study were determined by using criterion sampling, which is a purposeful sampling method. For the purposes of the study, a secondary school, where the researcher also works as guidance counsellor in Eskişehir, was chosen. The researcher is the guidance counsellor of the $5^{\text {th }}$ class in which there are 28 students and therefore 28 parents. The participation in the study was on voluntary basis and the researcher organized a meeting with the parents prior to parental coaching, in which she informed the parents about the research and parental coaching and stated that the participation was on voluntary basis. 16 of the parents agreed to participate in the study. These parents were informed about the name and goal of the group created on the social network as well as the roles of the researcher and the parents. The main criteria used in the determination of the participants were that the parents were the parents of 5 th grade students, they were the parents of the students who attended the class where the researcher was the classroom teacher, and only one parent was accepted as a participant (mother, father, or when both were not available, an individual who was responsible with the student) for each student. The researcher conducted the study especially with the parents of 5 th grade students. This is mainly due to the fact that the $5^{\text {th }}$ grade is the first step in the transition to secondary school in Turkey. In the first four grades, which are considered as the primary school in Turkey, single teacher conducts all instruction, however, starting with the $5^{\text {th }}$ grade (first year in secondary school), each course is instructed with an infield teacher, in other words each course is instructed by a different teacher. The transition period from primary school to the secondary school leads to problems for the parents to adapt to the evolving teacher-parent associations. The study was conducted with the parents of the students who attended the class where the researcher provided counseling services. This was due to the fact that guidance counselor of the class is responsible with the academic, physical, social and psychological development of the students in this classroom to cooperate with the parents. This enabled the more active and more natural participation of the parents in the study. Although the researcher acts as the guidance counselor of the class, she does not instruct any graded courses. Furthermore, the researcher stated in a pre-study meeting conducted with the parents that they can participate in the study on a volunteer basis. The researcher also continued to meet other parents that did not participated in the study within the context of face-to-face parent-teacher meetings during the study. The researcher 
devoted similar time to the non-participating class parents as the parents that participated in the study when they were willing to support their children's learning and acted in fairness towards all parents. The work conducted by the researcher with all parents as the guidance counselor is also supervised by the school administration since the researcher is a member of the official staff at the school. Besides the parents have the liberty to communicate their complaints about the guidance counselor of the class to the school administration in case the researcher acts in bias towards the children of the parents who participated in the study or the parents themselves. No complaints were raised by the school administration or the parents who did not participate in the study, either because the teacher was biased or there was a relationship between the parents and the teacher based on self-interest in the study process. The demographic information of the participants is displayed on Table 1.

Table 1. Demographical Properties of Participants

\begin{tabular}{|c|c|c|c|c|c|c|c|c|c|c|c|c|}
\hline \multicolumn{2}{|c|}{ Gender } & \multicolumn{4}{|c|}{ Educational background } & \multicolumn{4}{c|}{ Occupation } & \multicolumn{2}{c|}{ Age } \\
\hline Female & Male & $\begin{array}{c}\text { Primary } \\
\text { school }\end{array}$ & $\begin{array}{c}\text { Secondary } \\
\text { school }\end{array}$ & $\begin{array}{c}\text { High } \\
\text { school }\end{array}$ & University & Housewife & Employee & Officer & Self-employment & Retired & $\begin{array}{c}31-40 \\
\text { years }\end{array}$ & $\begin{array}{c}\text { Over the } \\
\text { age of } 40\end{array}$ \\
\hline 12 & 4 & 3 & 4 & 7 & 2 & 8 & 4 & 1 & 2 & 1 & 10 & 6 \\
\hline
\end{tabular}

As shown in Table 1, majority of the participants are mothers. 12 mothers and 4 fathers participated in the study. While majority of the parents are high school graduates, 3 are primary school and 2 university graduates. 8 of the mother parents are housewife; four parents are workers, one parent civil servant and one retired. Two parents are self-employed. Since the study focuses on Internet and Facebook use, the data regarding such use was also collected from the participants and the results are presented in Table 2 below.

Table 2. The Internet and Facebook Usage Duration of Participants

\begin{tabular}{|c|c|c|c|c|c|c|c|c|c|c|c|}
\hline & \multicolumn{2}{|c|}{$\begin{array}{c}\text { Usage Status } \\
\text { of Internet }\end{array}$} & \multicolumn{4}{|c|}{ Usage Frequency of Internet } & \multicolumn{4}{c|}{ Daily Usage Time of Internet } & \multicolumn{2}{c|}{$\begin{array}{c}\text { Usage Status of Facebook } \\
\text { Social Network }\end{array}$} \\
\hline & Yes & No & If it is necessary & $\begin{array}{c}2-3 \text { hours } \\
\text { a day }\end{array}$ & $\begin{array}{c}1-2 \text { hours } \\
\text { a day }\end{array}$ & $\begin{array}{c}\text { If it is } \\
\text { necessary }\end{array}$ & $\begin{array}{c}\text { Between } 2 \\
\text { pm-4 pm }\end{array}$ & $\begin{array}{c}\text { Between } 8 \\
\text { pm-22 pm }\end{array}$ & $\begin{array}{c}\text { Between } 9 \\
\text { am-18 pm }\end{array}$ & Yes & No \\
\hline $\mathrm{f}$ & 13 & 3 & 2 & 4 & 7 & 2 & 1 & 9 & 1 & 10 & 6 \\
\hline
\end{tabular}

Majority of the participants stated that they use the internet; 7 parents 1-2 hours a day, 4 parents 2-3 hours a day. Two parents stated that they are not regular internet users and they access the internet only when they need. Most of the participants use the internet in the evenings and only two parents stated that they do not have regular hours for internet use. One parent stated that he/she uses the internet between 14:00 and 16:00 and another between 9:00 and 18:00. 10 participants stated that they have a Facebook social network account and 6 of them do not.

\subsection{Data Collection Tools}

The data for the study was collected through "family information form", "social network group logs", "semi-structured interviews conducted with the parents and the students", "students' academic achievement scores", and "the questionnaire prepared specifically for the parents".

\subsubsection{Family Information Form}

Family information questionnaire was used to obtain parental demographics, which were considered to be significant for the parental coaching that would be conducted for the parents in the study. In the process of construction of the item pool for the questionnaire, several studies in the literature were examined $[17,38,39,50,54,68]$. The researcher reviewed the item pool that included 25 items and the number of items was reduced to 21 and the final form was presented for expert view. Face validity was used to determine the content validity of the questionnaire in the study. Experts' opinions were obtained to determine whether the language of the questionnaire was comprehensible and whether the items measured the desired properties. Necessary corrections and changes were done on the items based on the opinion of the experts that included one linguist, one counseling teacher, one faculty member in the faculty of education, computer and the teaching technologies department, and one faculty member in the faculty of education, educational programs and instruction department. The finalized questionnaire was applied to 10 parents with children in the 5th grade and with similar characteristics to the study participants. The pilot study was conducted to determine whether the parents experienced difficulties in comprehending the questionnaire. It was stated that the subjects did not experience any difficulties in comprehending any questionnaire item as a result. All parents stated that the questions were clear and comprehensible. 
This questionnaire consists of three parts. The first part includes 8 close-ended questions focusing on the personal information about the parents; which asks about their age, educational background, whether the child is foster or not, whether other members of the family are alive or not, and marital status. In addition, the participants were asked about their internet use and social network access in terms of frequency and time periods used daily or weekly. The second part of the questionnaire consists of 11 open-ended questions about supporting behaviors of the parents to help their children learn better, learning skills of their children and their academic achievement as well as the psychological traits that are believed to affect their child's education negatively. In the last part, two open-ended questions were asked to obtain data about parents' expectations from the researcher.

\subsubsection{Focus Group Discussion Conducted to Determine the Expectations of Parents regarding SNPC Application}

A focus group discussion with family was conducted once before the parental coaching via social network was initiated. The focus group discussion was conducted at the school meeting room. The date and time of the meeting were determined by the participants. The meeting room was organized to host 16 parents comfortably and to enable eye contact between each parent and the researcher. The focus group discussion was intended to be conducted with 16 participating parents, however 13 parents were able to participate since the two parents were at work on time of the meeting and one parent could not participate in the meeting due to illness. During the focus group discussion, an audio recorder was presented on the meeting desk. The discussion started with the introduction of the researcher providing contextual information and the permission of the parents for the scientific use of the data obtained from each participant. Later on, the sufficient general information about the study was provided for the parents. The researcher explained the objective and the general outline of the focus group discussion and initiated the focus group discussion by asking the first question. The researcher posed three open ended questions to the parents: what were the topics that the students experienced the most problems with; parents' views on the sources of these problems; and their expectations about the parent support program that would be conducted on social network settings. The data obtained provided information on the general structure and content of the parental coaching that the researcher aimed to conduct on social networks before the implementation, and what kind of posts would draw more attention of the parents and increase the parent involvement.

\subsubsection{Parental Coaching Social Network Group Logs}

They include working sheets completed by children under the supervision of the parents and guidance of the researcher through parental coaching, the comments about the shares in social network, likes, discussions and shares by the parents (picture, video, file) and private messages sent to the researcher via the network. Social network logs are used to obtain data regarding parent-teacher, parent-parent and parent-child interactions and to determine the expectations of the parents about their support for their children's learning.

\subsubsection{Semi-structured Interviews Carried out to Obtain Parents' Opinions Regarding SNPC Application and Their Interactions}

It is a 6-question form prepared specifically for the parents. Before the interviews, the form was presented to expert opinion and certain changes were made according to the feedback received. The form aims to obtain data from the parents regarding the efficiency of parental coaching through social network and their contribution to their children's learning process. Therefore, there were questions about supporting skills parents acquired thanks to parental coaching as well as knowledge and skills they provide for their children. In addition, the data about how social network application affects parents' interaction / communication with guidance counsellor (the researcher), with their children and other parents and how useful they found the application in terms of their support for the education of their children were also obtained. Another question asked in the interview is whether they face any problems during parental coaching practice or not and how they solved the problems faced, if there were any.

\subsubsection{Semi-structured Interview with Children to Obtain their Opinions Regarding SNPC Application and Their Learning}

It is a 5-question form prepared specifically for the children of the participant parents. Before the interviews, the form was presented to expert opinion and certain changes were made according to the feedback received. The questions asked were about parents' awareness of parental coaching, the activities they participated in and how parental coaching affects their communication with their families and their academic achievement. Another question asked in the interview is whether they faced any problems during parental coaching practice and how they solved these problems.

\subsubsection{The Questionnaire Prepared to Obtain Parents' Opinions about the Benefits of SNPC Application}

It was administered to the parents in order to support the ideas obtained from the interviews with parents about parental coaching application. Having 21 questions, the draft form was presented for expert opinion and later 4 questions were excluded from the form and the final version included 17 questions. This final version was reviewed for language problems and necessary changes were made accordingly. 


\subsubsection{Academic Achievement Scores of the Students}

They are the scores of written pre and post-tests administered by the teachers of each course which are related to the activities carried out through social network group according to the expectations of parents from the researcher.

\subsection{Data Analysis and Interpretations}

Both qualitative and quantitative data were collected in this study. Descriptive analyses were applied to analyze qualitative data. Wilconson $t$ test was used to analyze academic achievement scores - which is quantitative data. Finally, the data obtained from the questionnaire prepared to obtain parents' opinions about the advantages of parental coaching application through social network were analyzed by using percentages, frequencies and mean scores. The findings from both qualitative and quantitative data analysis were interpreted based on the research questions. To ensure the reliability of qualitative data, at least $30 \%$ of the data were presented to different experts, and Miles and Huberman (1994) were taken as the basis for reliability coefficient between coders (consensus).

\section{Results}

\subsection{Organization of Social Network Parental Coaching (SNPC)}

Parental coaching is an approach aiming to support parents. Parental coaching focusing on children's education is based on guiding parents by the experts in terms of the ways to establish healthy relationships by considering the needs of children, to support their school learning in out of school environments and to help them to be more successful. In this study, the expert is the researcher, who is also the guidance counsellor of the class, and the application area is the educational group created through Facebook social network. The organization of parental coaching consists of three phases: preparation, implementation and evaluation. The phases of SNPC application and the procedures for each phase are explained below:

\subsubsection{Preparation Phase of SNPC Application}

Before progressing to implementation phase, which covers the sharing of activities in SNPC application, preparation phase was followed between April $10^{\text {th }}$ and $25^{\text {th }}$ 2015. Figure 1 displays the preparation phase of SNPC application as a diagram.

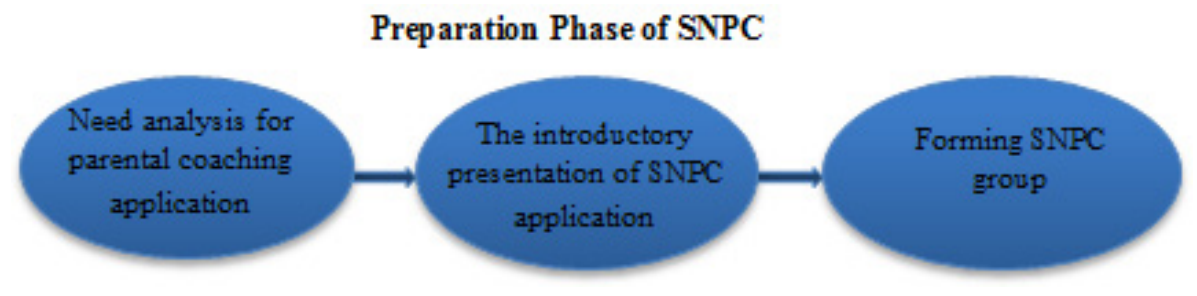

Figure 1. The Schematic Diagram of the Preparation Phase of SNPC

As shown in Figure 1, these preparation works include the need analysis focusing on parents, introductory presentation of SNPC application, creating the SNPC group and adding parents to the group as members. These preparations are explained in subtitles below:

Need analysis for parental coaching application: The content and scope of parental coaching and the issues for which parents will be guided can vary depending on the needs of the specific group. Therefore; certain works were done to determine the content of the application as well as a need analysis addressing to the participant parents. The data obtained helped the researcher to determine what educational issues are demanded by the parents in SNPC application. Parents were asked in what ways they can support the education of their children and in what issues they feel inadequate. The data obtained are displayed in Table 3. 
Table 3. The Supportive Activities Parents Done for Their Children's Education

\begin{tabular}{|c|c|c|c|c|c|c|c|c|c|c|c|c|c|}
\hline & \multicolumn{6}{|c|}{ The Courses Parents Helped } & \multicolumn{5}{|c|}{ The Supportive Activities of Parents } & \multicolumn{2}{|c|}{$\begin{array}{l}\text { The Educational } \\
\text { Websites Used }\end{array}$} \\
\hline & $\begin{array}{c}\text { All courses } \\
\text { except } \\
\text { English }\end{array}$ & All lessons & $\begin{array}{c}\text { Turkish- Social } \\
\text { Sciences-Science and } \\
\text { Technology }\end{array}$ & $\begin{array}{l}\text { Turkish- } \\
\text { Painting }\end{array}$ & $\begin{array}{c}\text { Turkish-Social } \\
\text { Science-Education of } \\
\text { Religion and Ethics }\end{array}$ & $\begin{array}{c}\text { None of the } \\
\text { lessons }\end{array}$ & $\begin{array}{c}\text { Sending his } \\
\text { child to private } \\
\text { course }\end{array}$ & $\begin{array}{c}\text { Sending his } \\
\text { child to school } \\
\text { courses }\end{array}$ & $\begin{array}{c}\text { Having his child } \\
\text { search about the } \\
\text { lessons on the } \\
\text { internet }\end{array}$ & $\begin{array}{c}\text { Doing reviews } \\
\text { together with } \\
\text { his child }\end{array}$ & Nothing & Yes & No \\
\hline $\mathrm{f}$ & 3 & 4 & 2 & 3 & 2 & 2 & 3 & 8 & 2 & 2 & 2 & 4 & 12 \\
\hline
\end{tabular}

As displayed in Table 3, parents mostly help their children in verbal lessons. Parents are able to provide less help for English, Mathematics and Sciences lessons when compared to verbal lessons such as Turkish, Social Science etc. Most of the parents send their children to the weekend courses offered at the school to support their education. Three parents stated that their children take private courses and one parent told that his child both attends school courses and is given private courses. The data obtained show that sending their children to courses is perceived as a supporting activity by the parents. Two parents also stated that they search the Internet to get information related to the courses and do some revisions of the day's lessons together with their children at home. Two parents, on the other hand, told that they do not do anything to support the learning of their children. Four parents stated that they use online educational websites to support learning process and others do not use any educational websites to provide such a support.

The opinions of the parents regarding academic performance of their children are also obtained in the needs analysis carried out. Table 4 presents data about what parents think about their children's performance in courses and their talents. It also presents data about which courses they think their children are successful in.

Table 4. Parents' opinions about the performance of their children in courses

\begin{tabular}{|c|c|c|c|c|c|c|c|c|c|c|c|c|c|c|c|c|c|c|}
\hline & \multicolumn{2}{|c|}{$\begin{array}{c}\text { Is he successful in } \\
\text { his courses in } \\
\text { general? }\end{array}$} & \multicolumn{3}{|c|}{ Their Children's talents } & \multicolumn{7}{|c|}{ The courses children successful in } & \multicolumn{6}{|c|}{ The courses the children have problems with } \\
\hline & Yes & No & Sports & $\left|\begin{array}{c}\text { Sports- } \\
\text { Painting }\end{array}\right|$ & $\begin{array}{l}\text { Sports- } \\
\text { Music }\end{array}$ & Maths & $\begin{array}{l}\text { Science and } \\
\text { Technology }\end{array}$ & $\begin{array}{c}\text { Social } \\
\text { Sciences }\end{array}$ & Turkish & English & $\begin{array}{l}\text { Information } \\
\text { Technologies }\end{array}$ & $\begin{array}{c}\text { Education of } \\
\text { Religion and } \\
\text { Ethics }\end{array}$ & Maths & $\begin{array}{l}\text { Science and } \\
\text { Technology }\end{array}$ & $\begin{array}{c}\text { Social } \\
\text { Sciences }\end{array}$ & Turkish & $\begin{array}{l}\text { Education of } \\
\text { Religion and } \\
\text { Ethics }\end{array}$ & English \\
\hline $\mathrm{f}$ & 5 & 11 & 10 & 3 & 3 & 9 & 6 & 4 & 5 & 6 & 4 & 4 & 3 & 5 & 4 & 7 & 4 & 5 \\
\hline
\end{tabular}

According to the Table 4, parents often focus on main courses while evaluating the success or failure of their children at school. While five parents find their children successful in general, majority think they are not. All the children are believed to be talented in all branches of sports, three in drawing and three in music. According to the parents, majority of the children are successful in mathematics. It can be said that children are relatively less successful in verbal courses than sciences and mathematics-based ones. As the parents stated, the reason for this situation is that children's primary school teachers gave considerable importance to science and mathematics-based courses and gave more activities in these courses. When the courses that parents think their children are not successful in are considered, it can be said that they have some problems in English and Turkish lessons.

Other data obtained from the needs analysis involve parents' opinions about psychological traits that are believed to affect their children's learning negatively and opinions about their children's learning competencies. The researcher thought this information, which is displayed in the Table 5 will guide her to provide personal help by sending parents private messages when needs arise. 
Table 5. Parents' opinions about some psychological traits and learning competencies of their children's

\begin{tabular}{|c|c|c|c|c|c|c|c|}
\hline & $\begin{array}{c}\text { Regular study } \\
\text { habit }\end{array}$ & $\begin{array}{c}\text { Reading } \\
\text { habit }\end{array}$ & $\begin{array}{c}\text { Having obsessive } \\
\text { behaviours }\end{array}$ & $\begin{array}{c}\text { Being aggressive towards } \\
\text { his friends }\end{array}$ & $\begin{array}{c}\text { Being } \\
\text { introvert }\end{array}$ & $\begin{array}{c}\text { Having concentration } \\
\text { problems }\end{array}$ & Hyperactivity \\
\hline Yes & 6 & 5 & 5 & - & 8 & 9 & 8 \\
\hline No & 9 & 10 & 11 & 15 & 7 & 6 & 7 \\
\hline Sometimes & 1 & 1 & - & 1 & 1 & 1 & 1 \\
\hline
\end{tabular}

According to Table 5, more than half of the parents think that their children do not have regular study and reading habits. It was found that more than half of the students have psychological traits that might affect their learning negatively; such as being introvert, having concentration problems and hyperactivity. Only one parent stated that his child is sometimes aggressive towards his friends. Five parents told that their children have obsessive behaviors. The final data obtained from the needs analysis involve the expectations of the parents from the researcher. To achieve this purpose, the general expectations of parents from parental coaching to help their children and the issues they feel inadequate to provide such a support were determined. Table 6 presents the expectations of the parents:

Table 6. The issues parents feel inadequate

\begin{tabular}{|l|c|}
\hline $\begin{array}{l}\text { The issues for which the parents feel inadequate } \\
\text { themselves while supporting their children's learning }\end{array}$ & Frequency \\
\hline $\begin{array}{l}\text { Having sufficient academic knowledge about their children's } \\
\text { courses to help them }\end{array}$ & 7 \\
\hline Being able to save time for their children & 2 \\
\hline Communicating with their children & 8 \\
\hline Parents' expectations from the researcher & 8 \\
\hline $\begin{array}{l}\text { Helping them how to support their children for the courses } \\
\text { they are weak at. }\end{array}$ & 6 \\
\hline $\begin{array}{l}\text { Helping them how to support their children in developing } \\
\text { their reading habits. }\end{array}$ & 2 \\
\hline Being guided in helping their children gain study habits & 2 \\
\hline $\begin{array}{l}\text { Helping them to cope with their children's disruptive } \\
\text { behaviours at school }\end{array}$ & $\begin{array}{l}\text { Informing the parents about disruptive behaviours and } \\
\text { academic performance of their children. }\end{array}$ \\
\hline
\end{tabular}

As displayed in Table 6, the most common issue in which the parents feel inadequate while supporting their children's learning is insufficient academic knowledge they have. Four parents reported that they are not able to save time for their children and two stated that they cannot communicate with their children. Three parents told that they support their children well enough and do not have any inadequacies in this support. Majority of the parents wanted the researcher to help them how to support their children for the courses they are weak at and in developing children's reading habits. Another expectation of the parents from the researcher is to be guided in helping their children gain study habits. Two parents demanded that the researcher help them to cope with their children's disruptive behaviors at school and inform the parents about disruptive behaviors and academic performance of their children. The reason why only two parents asked for such a help might be that such information is already provided in the meetings held with parents at schools.

Based on the data obtained regarding the issues for which the parents need help, the researcher asked the following question to the parents via social network in order to determine which lesson and learning issue to start from in parental coaching:

"Dear parents, according to the data I obtained from the family information form, one of the issues you ask for help is how to support your children in the courses they are weak at. Which courses do you need help and what kind of help do you need? Let's talk about this first.

The parents reported that the course and the skill, which the children find difficult the most is to write a composition in Turkish course and that, they wanted to improve this skill in their children. Below are the statements of three parents about the issue:

"He is good at Turkish course but we are having problems with composition writing. They are quite successful when the exam is multiple choice but when it is about writing they find it hard"

"There were multiple choice exams since the first year of primary school, so there are not any problems with this type of exams but we have problems in writing."

"They are very bad at composition writing"

The other courses, which parents reported that their children have problems with, are Religion and English. Below are the opinions of two parents:

"Our scores in Religion course are quite low. They have problems especially with wars, for example"

"They get low marks in English"

On the basis of the data obtained, the researcher decided to plan to provide support for the development of composition writing skills. This support continued throughout the study as long as the need for support is demanded through social network by the parents.

The Introductory Presentation of SNPC Application: Since some of the parents volunteered do not have information about social networks and Facebook, they were given a presentation about what social network means, the features of Facebook social network and how to use it. Following the general information, the parents were also informed about: what parental coaching, the topic of this 
study means, how parent-teacher, parent-parent, and parent-student interaction can be established; and how parents can support their children's education.

Creating the SNPC group: The researcher created a Facebook group entitled "Eğitim Geliştirme Çalışmaları" (Education Development Studies). After the introductory presentation, Facebook accounts of the parents were listed. Necessary guidance was provided for the parents who volunteered for the study but did not have a Facebook account and they were shown how to use Facebook for half an hour a day for one week. Since their children know how to use Facebook, these parents were able to learn about Facebook with the help of their children as well. One week later, the parents were added to the group and the researcher sent the following first message via the network to the members.

"Hello; welcome to our group. When I looked at the internet use hours you mentioned in parent interview form, I learned that the common hours are generally between 21:00 and 23:00. Therefore, we will share some activities about how to develop composition skills of our children between 21:00 and 22:00"

In the first message, the researcher mentioned about the common hours for the internet use in the group. When all the parents were added to the group, which took one week, the next step - the implementation of SNPC applicationstarted.

\subsubsection{SNPC Implementation Phase}

The researcher, who is also the guidance counselor of the class, implemented SNPC Application. First of all, the researcher shared via the social network group considerable amount of content related to the course the children have difficulty with according to the demands of the parents. In addition, more content were shared focusing on developing positive attitude towards learning, regular study habits, reading books, using learning strategies, and self-study. Figure 2 displays SNPC implementation process as a diagram.

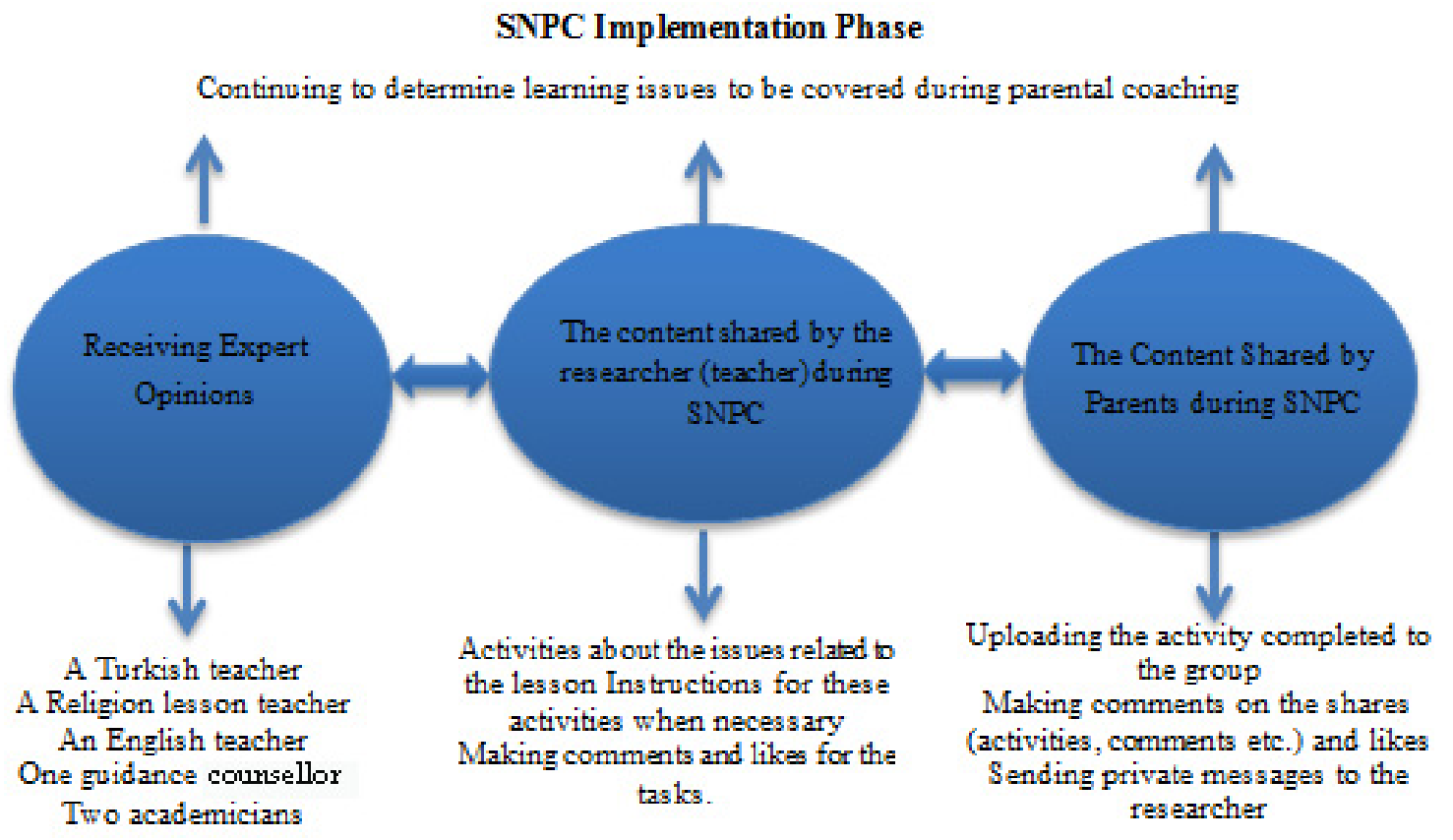

Figure 2. The Schematic Diagram of the Implementation Phase of SNPC 
As shown in Figure 2, implementation phase of parental coaching involves the following: the determination of learning issues to be covered in parental coaching; receiving expert opinion; and shared content by the parents and the teacher. The activities conducted during application process and the data obtained are explained below:

Continuing to determine learning issues to be covered during parental coaching: After the completion of parental coaching focusing on composition writing as demanded by the parents, the researcher asked about the next issue they would like to focus on. The following quotation reflects the parents' opinions about the issues to be focused on in parental coaching.

"English would be better, madam".

"Religion, if you ask me, madam. They have got an exam one month later about the life of our prophet and KANDILS (holy nights in Islam religion).

"We are having problems with Religion course"

"Good evening madam. It can be English".

"Good evening madam I think it can be English, too".

"Madam we want English".

"Madam English would be better".

As the opinions of the parents show, they mostly demanded parental coaching for English lesson. After the shares made for the topics in English lesson, the researcher shared new content for Religion lesson through social network. These shares were presented to expert opinion before they are shared in the group.

Receiving Expert's Opinions: While designing the activities related to the learning topics which are determined and based on the expectations of the parents, the researcher asked for expert's opinions. The parents reported that the lessons and topics, which need support the most, are composition writing in Turkish lesson, memorization of the topics-related vocabulary in English lesson, and wars and the dates of these wars covered in Religion lesson. The experts who took part in this study include a Turkish teacher, a Religion lesson teacher, an English teacher, one guidance counsellor, and two academicians - one from the department of educational programs, and another from the department of primary school teaching.

The Content Shared by The Researcher (Teacher) during SNPC: Based on the expert opinion received, the researcher shared activities about the issues related to the course specified by the parents and instructions for these activities when necessary. When these activities are completed by the children under the guidance of the parents and shared in the group, the researcher made encouraging and motivating comments and likes for these tasks. These comments were both aimed to motivate the parents and answer their questions related to the study.

The Content Shared by Parents during SNPC: The researcher decided on a certain period of time for each activity according to the content and goal of the activities and asked the parents to upload the activity completed to the group titled "Eğitim Geliştirme Çalışmaları" (Education Development Studies). The parents were able to make comments on these shares and like them. When they needed help, they were able to send private messages to communicate. The comments and likes are between researcher and parents as well as among parents.

\subsubsection{Ending SNPC Application and Evaluation Phase}

Carried out in the second semester of 2014-2015 academic year, the application lasted for two months and later ended because parents stated that they may not be able to participate regularly and efficiently due to summer holiday. In addition, the satisfaction from the answers of the parents to research questions is another reason to end the application. Figure 3 displays the ending and evaluation process of SNPC application as diagram.

\section{SNPC Evaluation Phase}

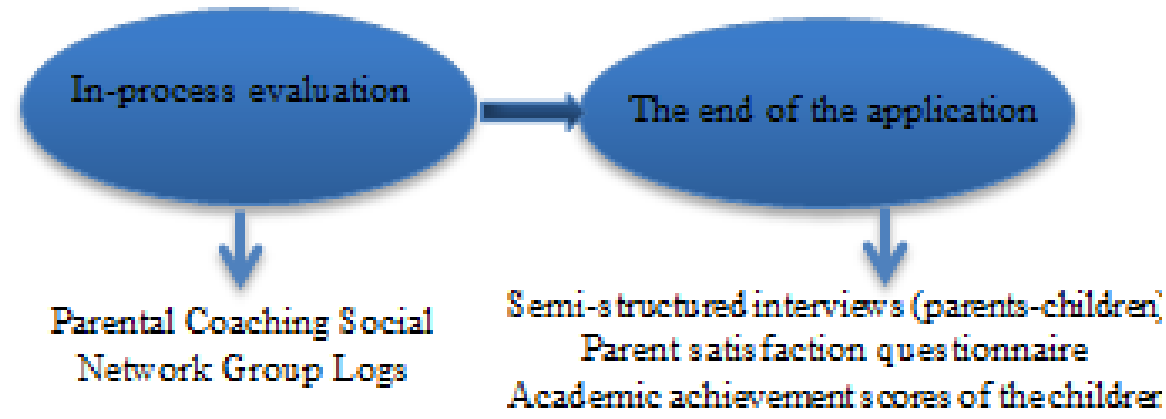

Figure 3. The Schematic Diagram of the Evaluation Phase of SNPC 
According to Figure 3, parental coaching via social network was evaluated both throughout the process and at the end of it. In-process evaluation is based on the comments and likes and activity shares by the parents. The data regarding evaluations at the end of the application were obtained through semi-structured interviews, parent satisfaction questionnaire and academic achievement scores of the children. The data obtained were explained below:

\subsection{The Interactions between Parents and Classroom Guidance Counselor during SNPC Application}

The frequency of parents' doing the activities shared by the researcher together with their children, the frequency of writing comments on or liking researcher's shares and semi-structured interviews were examined in order to determine the interaction between the researcher, who is also the guidance counselor of the class.

In average, the researcher shared content via social network once in two days. These shares included an activity related to the topics of the course in focus or important information, video, photograph or researcher's opinions about the topic. The frequency of teacher-parent interaction varies from parent to parent depending on the contribution of each parent. After each activity is completed under the guidance of the parents, it is uploaded to the group and published. When evaluated in a general sense, the first shares were not free from problems but they were solved in one week's time successfully. The photographs below show some of the activities completed by the children under the guidance of the parents and uploaded to the group:
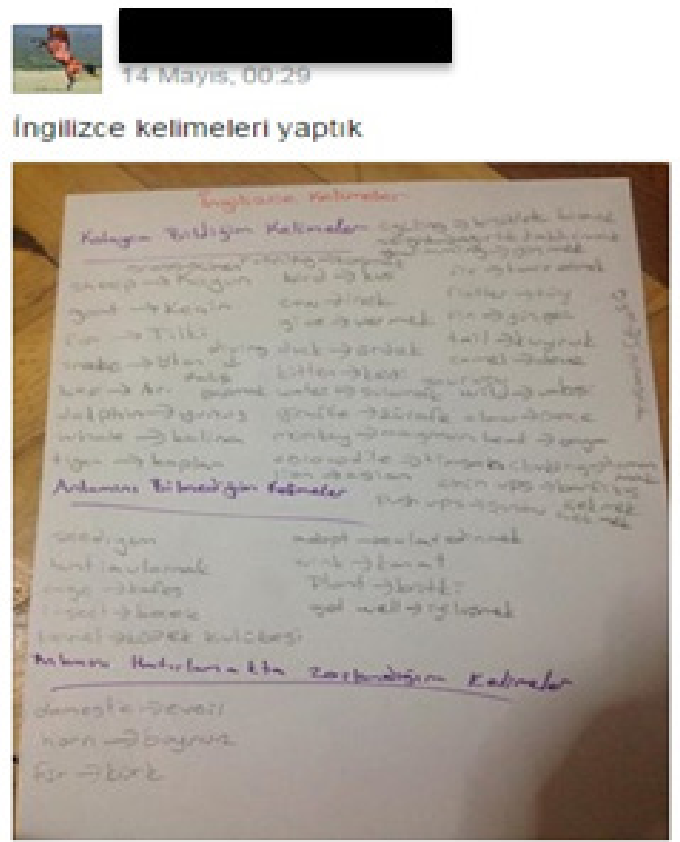

Photograph 1. One child's analysis study about his known and unknown English words
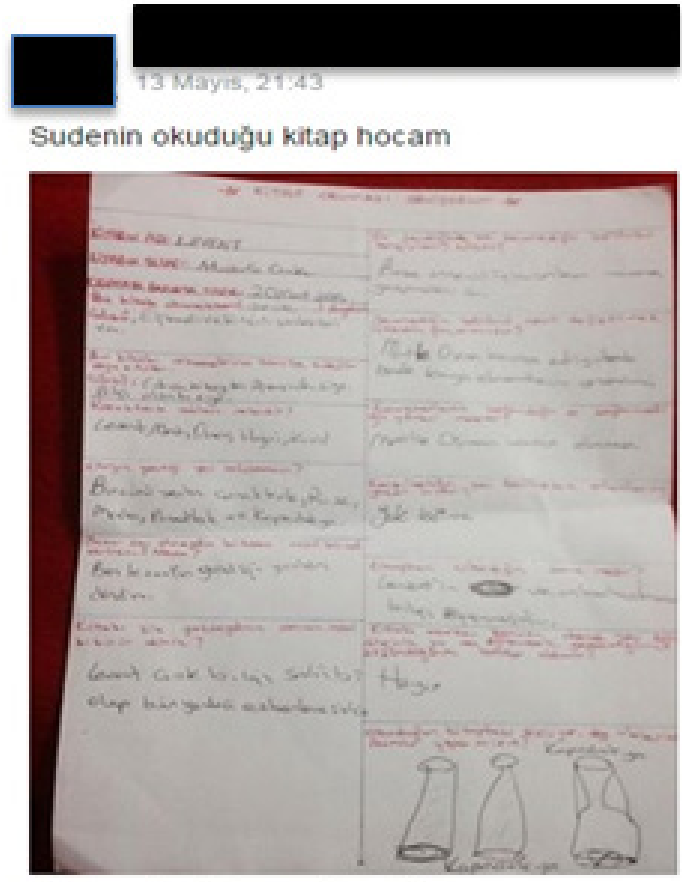

Beḡenmekten Vazgeç - Yorum Yap

Photograph 2. The summary of a book done by one child

Other criteria used to determine the success of teacher-parent interaction are the comments and likes of the parents for the content shared by the researcher. These comments often involved the questions about the activity, expressing their and their children's opinions about the activity, explaining how they carried out the activity or saying thanks. The following includes sample quotations from these comments:

"Madam, he wrote a summary of the storybook he read. We are doing the activities you shared too. It was better than the first one"

"Madam, she chose the shortest way and completed the composition very quickly as usual. I advised her to write slowly by thinking. And your explanations were very useful for my daughter. I hope next compositions will be better and longer."

In order to keep the interaction alive, the researcher replied to each activity shares and comments of the parents, expressed her positive or negative opinions and did some explanations if there were any problems and mistakes in the activities. Below are some examples of comments by the researcher to parents' shares.

"Well done Sude. She elaborated the topic a little more and provided more examples just like it should be in the development part of a composition"

"I will give some suggestions for the next book to read. First of all, we should make it a rule to read a few pages every day until she internalizes the reading habit. 
Almost all the parents liked the activities shared by the researcher. The reasons why the number of likes was higher than the comments might be that parents find it easier to like an activity than writing a comment about it. During the interviews conducted with the parents at the end of the application, they were asked how the application affected their interaction with the researcher, who is also the guidance counsellor of the class. All the parents interviewed stated that SNPC application increased teacher - parent interaction. Two parents stated their opinions about this as follows:

"It positively affected our communication with our class teacher. We are getting very useful information from our teacher. We are very pleased with her interest in and care about our children"

"Now we share knowledge with our class teacher. This is very nice. I want it to go on like that"

\subsection{The Interactions between Parents during SNPC Application}

In order to determine this type of interaction, the frequency of comments or likes by parents for each other's shares and semi-structured interviews conducted with the parents were taken into consideration. It was found that parents rarely preferred to write comment for each other's shares. Although they do not write any comments, they read, examined and liked each other's shares. During the interviews conducted with the parents, they were asked about their interaction with other parents in the group. Below are the opinions of three parents about this type of interaction:

\footnotetext{
"It was also effective for the communication among parents. Information sharing between the teacher and parents was easier by sharing activities and practices."

"We don't often write to each other as parents. We like each other's shares. This is also important"

"We, as parents, started to be interested more in our children. We are curious about what other parents did, how they did it. Sometimes we complete our missing points by looking at the completed activities"
}

As we can understand from the statements above, the data obtained from the interviews conducted with the parents clearly support the data obtained from social network logs.

\subsection{The Interactions between Parent and Child during SNPC Application}

Another stakeholder of parental coaching via social network is the children of the parents. Although the children are not active users of the social group, they are important for the study since they do the parental coaching activities together with their parents. During the interviews conducted with the parents, they were asked how parental coaching affected their interactions with their children. The opinions of three parents on this issue are presented below:

"My child is also pleased with this application. We started to study together more and more often. She is very careful and enthusiastic about the activities. We see the positive benefits of the application"

"Children follow the group enthusiastically. My child also waits for the task of the day impatiently. She asks whether the message has been received or not. It has been quite good for both of us. We study together delightfully. I find activities enjoyable too. We both enjoy them"

"We started to spend more time together for educational purposes. We started to do more lesson-related activities"

The data obtained from the interviews conducted with the parents at the end of the application revealed that parental coaching application increased their interaction with their children and was effective in increasing their support for their children's learning. A series of interviews were also conducted with the children of the parents and they were asked about the goal of parental coaching application and which activities they did. The reasons for asking such questions are to obtain data about whether the parents actively used SNPC application or not and whether children are aware of this application. Below are some samples from the opinions of the children about the goals of the application and the activities they did:

"The goals are to help us have closer relationships with our family, to guide our parents in showing better interest in us and to help us be better in our lessons"

"To increase our knowledge and to be better in our lessons are the goals, I think"

"To increase our success, to be better in our lessons, to be more successful in our exams. I think increasing our imagination is also one of the goals.

"We did story completion, composition (writing) and English words memorization activities"

"I did composition study about proverbs, I did activities in English, I wrote summaries for books".

All the students reported that the aim of the application is to increase their knowledge and help them be more successful in their lessons. In addition, some children mentioned about their families' interests in them more and an increase in their imagination. Also, it was found that the children completed majority of the activities shared via the network. The data obtained clearly show that the parents 
actively used the application and children are aware of the application. Another question asked to the children is how this application affected their interactions with their families. The opinions of two children are presented below:

"We did not use to spend time together beforehand, for instance my mother used to have her mobile in her hand and watch TV. She did not use to care (about me). Now we started to do (the activities / the homework) together, she started to help me"

"She was not able to help me with my lessons, now she started to help. For instance, she did not use to help with my homework beforehand. Now she asks whether I have homework or not. We do them together.

\subsection{The Problems Encountered during SNPC Applications}

Some problems were faced during different phases of SNPC application. These problems were presented in Table 7 below. According to Table 7, one of the problems encountered during the organization of parental coaching application is late membership to the group. Although parents were informed in the meeting about the day when the application will start, there were problems in joining the group in the first four days, during when the researcher had already shared one activity. After four days when all the memberships were completed, the application continued.

Table 7. The Problems Parents encountered during parental coaching application via social network

\begin{tabular}{|c|c|}
\hline The problems faced & $\mathrm{f}$ \\
\hline Some parents were late to join in the group & 4 \\
\hline Some parents did not know how to use social network & 2 \\
\hline Parents did not share the completed activities & 6 \\
\hline
\end{tabular}

As it can be seen in Table 7, another problem faced was that some parents did not know how to use Facebook social network. These parents were assisted in creating an account and they were shown how to use Facebook account for half an hour a day for one week. Since the children of these parents already knew how to use Facebook, they practiced and got experience in this use for one week before the actual implementation process. Six parents unfortunately couldn't share the activities completed by their children in the first week for various reasons. Four of these parents reported that they did the easy activities but did not do the difficult ones in the first week. Two parents sent private messages to the researcher to express their excuses as follows:

"Madam, we are sorry. The photographs of the activities we completed are not clear so we don't share our work in the group"

"We are doing the activities you suggest at home but I could not share with you due to my busy schedule. I read everything you share and do them. Thank you. I follow the group"

The data obtained from the interview conducted with the parents support those obtained from social network logs. The children were also asked during the interviews about the problems they encountered while doing the activities. The data obtained are similar to those obtained from the parents. Children also reported similar problems. Two parents and one child stated the following about the problems faced:

"I had difficult times at first since I didn't know how to use the internet, but later I got used to it" (Parent)

"My child is doing the activities you share, but I am not able to send them" (Parent)

"My father's computer did not have Microsoft Word program so he could not download some of the activities at the beginning but later he installed the program and downloaded. I did not find the activities difficult" (Child)

When the data obtained from social network logs and the interviews were analyzed, it can be found that the reasons for not sharing the activities in the group by the parents are "not doing each activity", "their busy schedule", "not knowing how to share photographs" and "low quality of the photograph". These problems were eliminated at the end of the first week. For instance, the parents who cannot share the completed activities due to busy schedule were told to share them when they have free time to do so in the following weeks.

\subsection{The Benefits of SNPC Application for $5^{\text {th }}$ Grade Secondary School Students' Parents}

In order to determine this contribution, the data obtained from the questionnaire and the interviews were used. The opinions of 16 parents were analyzed in the questionnaire. Table 8 displays the opinions of the parents regarding the benefits of the application. 
Table 8. Parents' Opinions Regarding the Benefits of the Application

\begin{tabular}{|c|c|c|c|c|c|c|c|}
\hline & \multicolumn{2}{|c|}{ Disagree } & \multicolumn{2}{|c|}{ Neutral } & \multicolumn{2}{|c|}{ Agree } & \multirow{2}{*}{ Mean } \\
\hline & $\mathrm{f}$ & $\%$ & f & $\%$ & $\mathrm{f}$ & $\%$ & \\
\hline Having more effective communication with my child's teacher about his education & 1 & 6.25 & 1 & 6.25 & 14 & 87.5 & 2.81 \\
\hline Being informed about educational websites and using them & - & - & 4 & 25 & 12 & 75 & 2.75 \\
\hline Providing more support for my child academically & 1 & 6.25 & - & - & 15 & 93.75 & 2.87 \\
\hline Being informed about the educational approach adopted by the guidance counsellor & 1 & 6.25 & - & - & 15 & 93.75 & 2.87 \\
\hline Recognizing good $/$ bad/weak/strong traits of my child & - & - & 3 & 18.75 & 13 & 81.25 & 2,81 \\
\hline Being informed about learning strategies and how to use them & - & - & - & - & 16 & 100 & 3 \\
\hline Realizing my mistakes and lack of knowledge in my support for my child's learning. & - & - & - & - & 16 & 100 & 3 \\
\hline Checking my child's studies/ homework for inadequate content & - & - & 1 & 6.25 & 15 & 93.75 & 2,93 \\
\hline Feeling more confident in terms of academic support I provide for my child & - & - & 1 & 6.25 & 15 & 93.75 & 2,93 \\
\hline $\begin{array}{l}\text { Showing my child how to use different resources such as dictionary, encyclopaedia, the } \\
\text { internet while doing his homework }\end{array}$ & - & - & - & - & 16 & 100 & 3 \\
\hline Talking to my child more about their lessons, homework and other activities at school & - & - & - & - & 16 & 100 & 3 \\
\hline $\begin{array}{l}\text { Benefiting from different resources such as books, journals, CDs while supporting my } \\
\text { child's education }\end{array}$ & - & - & - & - & 16 & 100 & 3 \\
\hline Following the changing and developing course contents and course books & - & - & 2 & 12.5 & 14 & 87,5 & 2,87 \\
\hline Having more effective communication with my child & 1 & 6.25 & - & - & 15 & 93.75 & 2.87 \\
\hline Creating suitable learning environments at home for my child & - & - & - & - & 16 & 100 & 3 \\
\hline Encouraging my child to question & - & - & 1 & 6.25 & 15 & 93.75 & 2,93 \\
\hline Giving opportunities to my child to be successful by themselves without getting any help & - & - & - & - & 16 & 100 & 3 \\
\hline
\end{tabular}

According to Table 8, all the parents who replied the questionnaire reported that SNPC application brought the following benefits: being informed about learning strategies and how to use them; creating suitable learning environments at home for their children; giving them opportunities to be successful by themselves without getting any help. In addition, the parents stated that they talked to their children more about their lessons, homework and other activities at school, and that they realized their mistakes and lack of knowledge in their support for their children's learning. Another important benefit that reported by all the parents is that they showed their children how to use different resources such as dictionary, encyclopedia and the internet while doing their homework and supporting their learning process. The least agreed statement in the questionnaire is "being informed about educational websites and using them". While 12 parents stated that the application had positive effect on this issue, four parents were undecided. One of the reasons why four parents are undecided about the statement might be that although the researcher shared the names of educational websites, she did not share any detailed information about how to use these websites. She mostly shared the activities she herself prepared. Three of the parents were undecided about the effects of the application on "recognizing $\mathrm{good} / \mathrm{bad} / \mathrm{weak} / \mathrm{strong}$ traits of their children; two were about the benefits of the application on following the changing and developing course contents and course books. As displayed in Table 8, all the parents except one stated that the application helped parents in the following issues: to provide more support for their children academically; to be informed about the educational approach adopted by the guidance counsellor; to check their children's studies / homework for inadequate content; to feel more confident in terms of academic support they provide for their children; to encourage them to question; and to have more effective communication with their children. The interviews conducted with the parents included questions about the benefits of parental coaching application for them and their children. Three parents stated their opinions as follows:

"Generally, I had the opportunity to learn about the problems the students face in their lessons or the topics. Since the activities my child did was consolidating, they were useful. The application became a good opportunity to get to know each other for the parents who do not know each other well or do not have any relationships."

"We used the educational websites suggested by our teachers. They contributed a lot to our learning. They were quite useful for my child."

"It helped us to foster our communication with our guidance counsellor. We were informed about our children's lessons together. We gained academic knowledge"

It was found that the data obtained from semi-structured interviews conducted with the parents clearly support the findings of the questionnaire. The benefits of the application are stated as follows: having more and effective 
communication with the guidance counsellor and their children; helping their children more in their lessons and obtaining information about their lessons.

\subsection{The Change in the Learning Levels of Children after SNPC Application}

In order to determine the change in the learning levels of children, the interviews conducted at the beginning and the end of the application process and the data obtained from their scores from the lessons in focus were used. It was examined whether there was meaningful difference between the scores they got from the written exams given as pre-test prior to the application and as the post-test two months later. The courses for which guidance was provided within the framework of SNPC application are Turkish, English and Religion. The table below presents descriptive statistics about pre-test and post-test scores.

Table 9. The descriptive statistics about pre-test and post-test scores of children

\begin{tabular}{|c|c|c|c|c|c|c|c|}
\hline & & \multicolumn{2}{|c|}{ Turkish } & \multicolumn{2}{c|}{ English } & \multicolumn{2}{c|}{ Education of Religion and Ethics } \\
\hline & $\mathrm{N}$ & $\bar{X}$ & $\mathrm{~s}$ & $\bar{X}$ & $\mathrm{~s}$ & $\bar{X}$ & $\mathrm{~s}$ \\
\hline Pre-test & 17 & 78,70 & 11,12 & 67,52 & 19,84 & 72,05 & 8,67 \\
\hline Post-test & 17 & 86,58 & 9,48 & 78,88 & 15,65 & 91,17 & 7,81 \\
\hline
\end{tabular}

Table 9 shows that post-test mean scores of the children from all three courses are higher than pre-test scores. Wilcoxon signed-rank test was applied to determine whether there were meaningful differences between pre-test and post-test scores. Table 10 displays Wilcoxon test results about pre-test post-test achievement scores:

Table 10. The Wilcoxon test results about pre-test and post-test achievement scores of Turkish Lesson

\begin{tabular}{|c|c|c|c|c|c|c|}
\hline Scores & Ranks & $\mathrm{N}$ & Mean Rank & Sum of Ranks & $\mathrm{z}$ & $\mathrm{p}$ \\
\hline \multirow{4}{*}{$\begin{array}{l}\text { Turkish lesson pre-test score } \\
\text { Turkish lesson post-test score }\end{array}$} & Negative Ranks & 2 & 3,00 & 6,00 & \multirow{4}{*}{$-3,343$} & \multirow{4}{*}{, 001} \\
\hline & Positive Ranks & 15 & 9,80 & 147,00 & & \\
\hline & Ties & 0 & & & & \\
\hline & Total & 17 & & & & \\
\hline
\end{tabular}

$\mathrm{p}<.05$

According to Table 10, there is a meaningful difference between pre-test and post-test scores of the children for Turkish lesson. In other words, the learning levels of children in Turkish lesson increased after SNPC application. Another course focused in the application is English. Table 11 presents the results of Wilcoxon test results for pre-test post-test achievement scores for English lesson:

Table 11. The Wilcoxon test results about pre-test and post-test achievement scores of English Lesson

\begin{tabular}{|c|c|c|c|c|c|c|}
\hline Scores & Ranks & $\mathrm{N}$ & Mean Rank & Sum of Ranks & $\mathrm{z}$ & $\mathrm{p}$ \\
\hline \multirow{4}{*}{$\begin{array}{l}\text { English lesson pre-test score } \\
\text { English lesson post-test score }\end{array}$} & Negative Ranks & 1 & 4,00 & 4,00 & \multirow{4}{*}{$-3,435$} & \multirow{4}{*}{, 001} \\
\hline & Positive Ranks & 16 & 9,31 & 149,00 & & \\
\hline & Ties & 0 & & & & \\
\hline & Total & 17 & & & & \\
\hline
\end{tabular}

$\mathrm{p}<.05$

As shown in Table 11, Wilcoxon test applied to test whether there was a statistically meaningful difference between pre-test and post-test scores for English lesson showed such a difference. In other words, the learning levels of the students meaningfully increased for English lesson after the SNPC application. Table 12 displays Wilcoxon test results for pre-test and post-test achievement scores for Religion lesson, which is another course lesson focused in the application:

Table 12. The Wilcoxon test results about pre-test and post-test achievement scores of Education of Religion and Ethics

\begin{tabular}{|c|c|c|c|c|c|c|}
\hline Scores & Ranks & $\mathrm{N}$ & Mean Rank & Sum of Ranks & $\mathrm{z}$ & $\mathrm{p}$ \\
\hline \multirow{2}{*}{$\begin{array}{c}\text { Education of Religion and Ethics lesson pre-test } \\
\text { score }\end{array}$} & Negative Ranks & 0 &, 00 &, 00 & \\
\cline { 2 - 5 } $\begin{array}{c}\text { Education of Religion and Ethics lesson post-test } \\
\text { score }\end{array}$ & Positive Ranks & 17 & 9,00 & 153,00 & \multirow{2}{*}{$-3,691$} & \multirow{2}{*}{001} \\
\cline { 2 - 5 } & Ties & 0 & & & \\
\cline { 2 - 5 } & Total & 17 & & & \\
\hline
\end{tabular}


According to Table 12, there is a meaningful difference between pre-test and post-test scores for Religion lesson. In other words, the learning levels of the students meaningfully increased for Religion lesson after the SNPC application.

For the purposes of determining the changes in the learning levels of children, the data obtained from the interviews conducted with the children was used in addition to achievement scores. The children were asked whether parental coaching application contributed to their learning. All the students reported positive contribution. When asked about these benefits, two students expressed their opinions as follows:

"It affected positively. For instance, I was bad at writing compositions in Turkish. Composition writing was (asked) in all exams. I had problems in punctuation. So it was useful in Turkish exams and I increased my scores. It was also useful for English lessons. For example, I benefitted from it for reading questions and illustrated questions. My score in English was 86, which increased to 92. Turkish was 76, which increased to 85 ."

"For instance, I did not use to like studying lessons. Especially, I did not like studying English, but I started to like English and study hard thanks to your activities. My score in English increased."

During the interviews, the parents were asked during the interviews conducted with them about the contribution of SNPC application to their children's learning. All the parents agreed on the presence of positive contributions. Below are the opinions of three parents:

"My child is now able to write more comprehensible compositions. He is better in English to some extent. He got a good score from Religion lesson"

"He developed a composition writing habit. He learned the vocabulary in the units in English lesson"

"He become a responsible person. He started to think about his lessons. I believe that his imagination increased. It became very useful especially for composition writing"

The data obtained from the interviews conducted with parents and their children are interpreted together with their academic achievement scores, and it can be concluded that SNPC application caused positive changes in the learning of the children.

\section{Discussion}

Learning process starts with the birth and continues with school education in a well-planned and programmed way. Therefore, it is essential to establish a strong collaboration between parents and teachers and guide parents in contributing to this education process in order to create an effective and successful learning environment. Although literature increasingly emphasizes the importance of parent-teacher collaboration, the studies conducted show that this collaboration is sometimes limited to financial issues of the class or school, and an effective and sufficient collaboration cannot be realized in order to increase students' academic success and the development of learning habits $[3,15,19,24]$. There are many family, teacher and student related factors for not being able to establish parent-teacher collaboration at schools. One of these factors is that parents and teachers cannot have face-to face interaction due to some reasons $[17,66]$. This study shows that these time and space limitations can be solved through parental coaching realized via network-based learning, which is often used effectively in many fields of education. In the related literature, it is suggested that technological tools such as e-mail, teleconferencing, fax, websites, phone messaging systems, text messaging, instant messaging and social networks can be used to communicate with parents in parallel with technological developments $[13,55]$.

Another important finding of the study is that parents consider "sending their children to school courses and hiring private teachers" as the most important support for their learning. It was observed that this was important in certain eastern countries similar to Turkey. It's very popular for students to attend extra-curricular lessons, for the potential positive effects, more frequently for their utilitarian benefits. These lessons are student-centered, scheduled outside normal school hours, formally organized and planned in accordance with students' ability and interest. Parents value them as a vital and essential supplement to general school curriculum [87].

In addition, the issue where parents see themselves insufficient regarding the support for learning process is that they do not have enough academic knowledge to help their children. The issue which parents ask for help the most from the researcher in this application is guidance for the ways to support their children in the courses they have problems with. These findings clearly show that majority of parents do not know how they can effectively provide academic support for their children's learning. Similarly, Öz (1983), states that parents are either not aware of the learning problems of their children or they do not know how to solve them even if they are aware of these problems [cited by 60]. Observations in private schools in Dubai also reveal that parents are often confused as to what is to be expected of them regarding their role in their children's education. They also question to what extent they can have a positive influence on their children [65].

One of the important issues emphasized in the related literature is that parents should be able to support their children in out-of-school environments as well by being equipped with necessary academic information and making school and home learning parallel and integrated $[22,72]$. 
Hoover-Dempsey and Sandler (1997) also stated that the knowledge and abilities of parents are important factors, which determine and affect parental involvement. They emphasized that the educational level of the family can influence parental involvement, not necessarily at the level of the involvement proper, but at the level in which it is manifested [58]. In addition, Shumow and Lomax (2009)'s research indicates that children do better academically, socially, and psychologically when their mothers perceive themselves as competent parents [17]. Similar to European countries, some Eastern countries place increasing emphasis on family education along with the contributions of the World Bank to the education in developing countries. Governments and non-governmental organizations in some of these countries that were sponsored by the World Bank have conducted studies on the education of parents with children in preschool or primary school age [70]. In eastern countries with high academic performance in international exams such as PISA, it was observed that parents place emphasis on the support that their children receive in out-of-school settings and on the information about the support they could provide for their children. In these countries, the schools organize courses for parents on the use of technologies and the instructional strategies to support the learning of their children [42].

According to the results of the study, parental coaching via social network (SNPC) increases parent-child interaction and parents feel more knowledgeable and equipped in supporting their children affectively and academically. Parents' ability to support their children more thanks to activities and information sharing, their feeling confident in providing such a support and being aware of their children's abilities and competencies positively affect their communication with their children, which in turn increase the academic achievement of children. This result is consistent with the results of many studies which reveal that the academic success of the children supported by their parents is higher $[2,5,6,29,35$, $41,43,44,48,49,62,68,84]$. In addition, literature states that the parents who have more communication with teachers and school, have the opportunity to recognize their children's abilities, area of interests and other characteristics more effectively [22, 23].

It can be concluded that the effective involvement of parents through the activities provided by the teacher via social network group also increase teacher-parent and parent-parent interaction.

Although there are few studies about parental coaching implemented via social networks in the related literature, the results of research focusing on parent-teacher association indicated that parental involvement benefits not only children themselves but also the teachers/practitioners, the setting and the parents themselves [17, 20]. According to researches' findings, parents who are involved in their child's schooling report improved communication with their child about schoolwork, more involvement in educational activities at home [Christenson 1995b cited in 26], satisfaction in their relationships with teachers, appreciation for the commitment of teachers, and increased parenting efficacy [Swap 1990 cited in 26. Lindberg and Oğuz [53] also suggest that parent involvement applications include all collaboration-based attempts and applications to support children's education and development, and this situation increases the interaction between family-teacher and school administration and even between school and society as a whole. In eastern countries with a high socio-economic level and high schooling rate, it was observed that parents are more likely to emphasize parental involvement. The results of a study conducted by Jabar [42] on Japanese families demonstrated that when families take on several tasks in parental involvement, the relationship between the parents and the school improved. Conversely, in eastern countries where parents do not have a say about decision-making processes at the school, school-parent association is not completely achieved, having adverse effects on their communication and parents do not participate in school-based parental involvement activities too often. In Turkey, it was observed that parents are not effective on the decision-making processes in the school financial matters. While parents provide financial assistance to the schools, they do not have the authority to decide what the needs of the school are, what the priorities of these requirements are and how to meet these requirements. However, it could be stated that the parents contribute to the assessment and development of the school programs during recent years in Turkey. The content of parental coaching in SNPC application and the issues for which guidance will be provided vary according to the needs of the target population. Therefore, it is necessary to carry out activities to determine the content of the application, and parental coaching should be applied accordingly. Similarly, López (2001) emphasized that making the use of opportunities to facilitate parental involvement, such as offering incentives or strong rationales for such an involvement is important. This can take the form of covering information that is urgent or interesting and useful, such as skill development courses [1].

The experts who carried out parental coaching included the researcher, who was also the guidance counselor of the class, the teachers of the courses focused in the application and academicians. A similar parental coaching application can be realized in a more comprehensive way in terms of content and duration by forming a broader social network with all the teachers of the class, school guidance counselor and academicians. Similarly, this study, which is conducted with secondary school students, can be repeated with other levels of education such as primary school or high school in order to support parents who consider themselves insufficient in terms of support for their children's learning process. 


\section{REFERENCES}

[1] Aguayo, D. (2015). Family engagement in early childhood education through high school years. Parent and family engagement in higher education: AEHE, Kelly Ward and Lisa E. Wolf-Wend (eds). 41 (6), 18-25.

[2] Akay, Y. \& Küçükkaragöz, H. (2014). Aile katılımlı performans görevlerinin ilköğretim 5. Sınıf öğrencilerinin matematik dersi eriși ve tutumlarına etkisi. [The effect of performance tasks with parental involvement on the elementary 5th grade students' achievements and attitudes in mathematics lesson], Turkish Studies - International Periodical for the Languages, Literature and History of Turkish or Turkic, 9 (5), 47-66.

DOİ:http://dx.doi.org/10.7827/TurkishStudies.6586

[3] Akbaşl1, S., \& Kavak, Y. (2008). Ortaöğretim okullarındaki okul aile birliklerinin görevlerini gerçekleștirme düzeyleri. [The realization level of parent-teacher associations' roles in secondary schools], Selçuk Üniversitesi Sosyal Bilimler Enstitüsü Dergisi 19, 1-22.

[4] Arens, A.K. \& Jude, N. (2017). Parental involvement and student achievement in two language domains: Indirect relations and generalizability across migration status Learning and Individual Differences, 53, 145-155.

[5] Argon, T. \& Kıyıcı, C. (2012). İlköğretim kurumlarında ailelerin eğitim sürecine katılımlarına yönelik öğretmen görüşleri, [Teacher views in primary schools about parental participation in education], Dicle Üniversitesi Ziya Gökalp Eğitim Fakültesi Dergisi, 19, 80-95

[6] Aslanargun, E. (2007). Okul-aile işbirliği ve öğrenci başarısı üzerine bir tarama çalışması. [A survey study on parent-teacher association and students' academic achievement], Manas Üniversitesi Sosyal Bilimler Dergisi, 9(18), 119-135.

[7] Baskwill, J. (2013). Attention grabbing skills for involving parents in their children's learning. U.S: Stenhouse Publishers.

[8] Başaran, S. T. \& Koç, F. (2001). Ailenin çocuğun okuldaki eğitimine katılım sorunları ve katılımın sağlanması için alternatif bir model. [The problems of parent's involvement to their children's' school education and an alternative model to provide parental engagement], Ankara: Milli Eğitim Basımevi.

[9] Biller, K. (1997) Sosyal Felsefeci olarak 21. Yüzyılın Öğretmenleri. [The 21st century teachers as a social philosopher], Uluslararası Dünya Öğretmen Eğitimi Konferans1, Ankara: Milli Eğitim Basımevi.

[10] Bouffard, S. M. (2008). Tapping into technology: The role of the Internet in family- school communication. Cambridge, MA: Harvard Family Research Project.

[11] Calderhead, J. (1997). Öğretmenlerin Uzmanlığının Tanınması ve Geliştirilebilmesi. [The recognition and development of teachers' specialists], Uluslararası Dünya Öğretmen Eğitimi Konferans1, Ankara: Milli Eğitim Basımevi.
[12] Carneiro, P. (2008). Equality of opportunity and educational achievement in Portugal. Portuguese, Economic Journal, 7 (1), 17-41.

[13] Çayak, S. (2013). Öğretmen-veli işbirliği ile ilkokul ögrencilerinin sınıf içindeki istenmeyen davranışları arasındaki ilişki. [Relationship between teacher-parent cooperation and primary school students' undesirable behaviors in the classroom], (Unpublished Master's Thesis) Trakya Üniversitesi, Eğitim Bilimleri Enstitüsü, Edirne.

[14] Çelenk, S. (2003). Okul başarısının ön koşulu: okul aile dayanışmasi. [The prerequisite of school success: the teacher-parent solidarity], İlköğretim-Online, 2 (2), s. 28-34.

[15] Çelik, N. (2005). Okul-aile ilişkilerinde yaşanan sorunlar. [The problems in relationship between teacher-parent cooperation], (Unpublished Master's Thesis), Marmara Üniversitesi, İstanbul.

[16] Chairatchatakul, A., Jantaburom, P. \& Kanarkard, W. (2012). Using social media to improve a parent-school relationship. International Journal of Information and Education Technology, 2(4), 378-381.

[17] Chung, G.H., Lee, H., Lee, J. \& Lee, K. (2015). A mediational model of school involvement, knowledge about a child's school life, and parental efficacy among South Korean Mothers. Journal of Child and Family Studies, 24, 899-908.

[18] Curtiss, S., Pearson, J., Akamoğlu, Y., Fisher, K., Snodgrass, M., Meyer, L., Meadan, H. \& Halle, J. (2015). Bringing instructional strategies home: Reaching families online. Teaching Exceptional Children, 48(3), 159-167.

[19] Demirbulak, D. (2000). Veli-öğretmen görüşmeleri ile ilgili bir çalışma. [A study about teacher-parent meetings], Millî Eğitim Dergisi, 146, 53-55.

[20] Dickins, M. (2014). A-Z of inclusion in early childhood, New York: McGraw-Hill Education.

[21] Duggan, M., Lenhart, A., Lampe, C. \& Ellison, N.B. (2015). Parents and social media. Pew Research Center, 1-36. Retrieved from

http://www.pewinternet.Org/2015/07/16/parents-and-social -media/.

[22] Epstein, J. L. (1995). School/family/community partnerships: Caring for the children we share. Phi Delta Kappan, 76 (9).

[23] Epstein, J. L. \& Sheldon, S. B. (2002). Present and accounted for: Improving student attendance through family and community involvement. The Journal of Educational Research, 95 (5), 308- 318.

[24] Erdoğan, Ç.\&Demirkasımoğlu, N. (2010). Ailelerin eğitim sürecine katılımına ilişkin ögretmen ve yönetici görüşleri. [Teachers' and school administrators' views pf parental involvement in education process], Kuram ve Uygulamada Eğitim Yönetimi, 16(3), 399-431.

[25] E-safety support (2013). What every teacher needs to know about social media. Retrieved from http://www.staidanscatholicacademy.co.uk/wp-content/uplo ads/2015/02/What-every-teacher-needs-to-know-about-soci al-media.pdf. 
[26] Fishman, C. E. \& Nickerson, A.B. (2014). Motivations for involvement: A preliminary investigation of parents of students with disabilities, Child Family Studies, 24, 523-535.

[27] Gonzalez- DeHass, A., Willems, P. P. \& Holbein, M. D. (2005). Examining the relationship between parental involvement and student motivation. Educational Psychology Review, 17, 99-123.

[28] Gordon, T. (1993). Etkili Öğretmenlik Eğitimi. [An effective teacher education], (Çev: Emel Aksay ve Birsen Özkan.) İstanbul: YA-PA Yayınları.

[29] Grayson, H. (2013). Rapid Review of Parental Engagement and Narrowing the Gap in Attainment for Disadvantaged Children. National Foundation for Educational Research and Oxford University Press

[30] Gökçe, E. (2002). İlköğretim Öğrencilerinin Görüşlerine Göre Öğretmenlerin Etkililiği, [Views of elementary school students with regard to teachers' efficiency], Ankara Üniversitesi Eğitim Bilimleri Fakültesi Dergisi, 35 (1-2), 113-119.

[31] Graham-Clay, S. (2005). Communicating with parents: Strategies for teachers. School Community Journal, 16(1), 117-129.

[32] Gültekin, M. \& Anagün, Ş. (2006). Avrupa Birliğinin eğitimde kaliteyi belirleyici alan ve göstergeleri açısından Türk eğitim sisteminin durumu. [The condition of Turkish education system from the aspect of European Union's area and indicators determining the quality in education], Sosyal Bilimler Dergisi, 145-170.

[33] Hernandez-Cruz, I. \& Russell, D. (2016). Social media: Connecting with parents-Understanding how social media can influence parental involvement. Public Schools of North Carolina, State Board of Education. Retrieved from http://www.ncpublicschools.org/docs/intern-research/report s/socialmediaparents.pdf.

[34] Hester, H. (1989). Start at home to improve home-school relations. NASSP Bulletin, 73(513), 23-27.

[35] Hill, N. E., \& Tyson, D. F. (2009). Parental involvement in middle school: A Meta-analytic assessment of the strategies that promote achievement. Developmental Psychology, 45(3), 740-763.

[36] Ho, S.C. (1995). Parent Involvement: A comparison of different definitions and explanations. Education Journal 23: $39-68$.

[37] Holloway, S., Yamamoto, Y., Suzuki, S. \& Mindnich, J. (2008). Determinants of parental involvement in early schooling: evidence from Japan, Ealey Childhood Research \& Practice, 10(1), 1-21.

[38] Hower-Dempsey, K. V., Walker, J.M.T. \& Sandler, H.M. (2005). Parents' motivations for involvement in their children's education. In E. N. Patrikakou, R. P. Weisberg, S. Redding \& H. J. Walberg (Eds.), School-family partnerships for children's success, 40-56, New York: Teachers College Press.

[39] Huang, C. \& Dong, N. (2014). Dimensionality of the children's depression inventory: Meta-analysis of Pattern Matrices, Journal Child Family Studies, 23: 1182-1192.
[40] Huntsinger, C. \& Jose, P. (2009). Parental involvement in children's schooling: Different meanings in different cultures. Early Childhood Research Quarterly, 24, 398- 410.

[41] İpek, C. (2011). Velilerin Okul Tutumu ve Eğitime Katılım Düzeyleri ile Aileye Bağlı Bazı Faktörlerin İlköğretim Öğrencilerinin Seviye Belirleme Sınavları(SBS) Üzerindeki Etkisi, [The effects of parent's educational involvement, school attitudes and some family related factors on the primary school students' national level assessment test scores], Pegem Eğitim ve Öğretim Dergisi, 1 (2), 69-79.

[42] Jabar, M.A. (2010). How do Japanese schools promote parental involvement? International journal of social sciences and humanity studies. 2(1), 91-98.(Parental involvement in Japanese)

[43] Jeynes, W. H. (2007). The relationship between parental involvement and urban secondary school student academic achievement: A meta-analysis. Urban Education, 42(82).

[44] Jeynes, W. H. (2012). A Meta-analysis of the Efficacy of Different Types of Parental Involvement Programs for Urban Students. Urban Education 47 (4), 706-742.

[45] Kalafat, Ö. \& Göktaş, Y. (2011). Sosyal ağların yükseköğretimde kullanımı: Gümüşhane Üniversitesi, Facebook örneği. [Usage of social networks in higher education: University of Gümüşhane, Sample of Facebook], 5th International Computer \& Instructional Technologies Symposium, Firat University, Elazığ- Turkey

[46] Kebeci, S. (2006). Okul-aile birliğinin okul performans1 üzerinde rolü, [The roles of parent-teacher association on school performance], (Unpublished master's thesis), Marmara Üniversitesi Sosyal Bilimler Enstitüsü, İstanbul.

[47] Keith, T. Z., Keith, P. B., Kimberly, J. Q., Sperduto, J., Santillo, S., \& Killings, S. (1998). Longitudinal effects of parent involvement on high school grades: similarities and differences across gender and ethnic groups. Journal of School Psychology, 36 (3), 335-363.

[48] Kotaman, H. (2008). Türk ana babalarının çocuklarının eğitim öğretimlerine katılım düzeyleri. [The Turkish parental involvements levels to their childrens' education], Uludağ Üniversitesi Eğitim Fakültesi Dergisi, 21(1), 135-149.

[49] Kung, H. \& Lee, C. (2016). Multidimensionality of parental involvement and children's mathematics achievement in Taiwan: Mediating effect of math self-efficacy, Learning and Individual Differences, 47, 266-273.

[50] Kuzucu, Y. \& Cebeci, S. (2005). Okul PDR (Psikolojik Danışmanlık ve Rehberlik) Uygulamaları için 9 Form [9 Form for school psychological counseling and guidance]. Ankara: Mamak Rehberlik ve Araştırma Merkezi Yayını.

[51] Lau, E., Li, H. \& Rao, N. (2011). Parental involvement and children's readiness for school in China. Educational Researchc, 53(1), 95-113.

[52] Lawson, M. A. (2003). School-family relations in context: parent and teacher perceptions of parent involvement. Urban Education, 38, 77-133.

[53] Lindberg, E. \& Oğuz, K. (2016). İlkokul ve ortaokullarda aile katılımı: Bir geçerlilik ve güvenirlilik çalışması [Family involvement at elementary school: A validity and reliability 
study]. Journal of Human Sciences, 13 (3), 4135-4151.

[54] Millones, D.L., Ghesquiere, P. \& Leeuwen, K. (2014). Evaluation of a parental behavior scale in a Peruvian context. Journal Child Family Studies, 23, 885-894.

[55] Olmstead, C. (2013). Using technology to increase parent involvement in schools. Tech Trends, 57(6), 28-37.

[56] Partnership for $21^{\text {st }}$ Century Learning- P21 (2007). Framework for $21^{\text {st }}$ century learning. Retrieved from www.P21.org

[57] Patrikakou, E.N. (2016). Parental involvement, technology, and media: Now what? School Community Journal, 26 (2).

[58] Pavalache-Iliea, M. \& Tîrdia, F. (2015). Parental involvement and intrinsic motivation with primary school students. Procedia-Social Behavioral Sciences, 187, 607-612.

[59] Pollara, P. \& Zhu, J. (2011). Social Networking and Education: Using Facebook as a Eusocial Space. Proceedings of Society for Information Technology \& Teacher Education International Conference, Chesapeake, VA: AACE. p. 3330-3338.

[60] Porsuk, A. \& Kunt, M. (2012). Denizli merkez ilköğretim okullarındaki okul aile ilișkilerinde karșılașılan sorunlar üzerine yönetici görüşleri. [Denizli elementary school administrators' opinions on the problems faced during school-family relations], Pamukkale Üniversitesi Eğitim Fakültesi Dergisi, 31, 203-218.

[61] Robinson, K. \& Harris, A. (2014). The Broken Compass: Parental Involvement with Children's Education, Cambridge: Harvard University Press

[62] Shaw, C. A. (2008). A study of the relationship of parental involvement to student achievement in a Pennsylvania career and technology center. (Unpublished doctoral dissertation), The Pennsylvania State University, Pennsylvania, USA.

[63] Sheldon, S. B. (2003). Linking school-family-community partnerships in urban elementary school to student achievement on state tests. The Urban Review, 35 (2).

[64] Sheldon, S. B. (2007). Improving student attendance with school, family, and community partnerships. The Journal of Educational Research, 100(5), 267-275.

[65] Sumaiti, R. (2012). Parental involvement in the education of their children in Dubai. Dubai School of Government Policy Brief No: 30, Dubai School of Government. 1-8.

[66] Syamsudduha, S. \& Ginanto, D. (2017). Parental involvement in Indonesia, 66, 1st Yogyakarta International Conference on Educational Management/Administration and Pedagogy (YICEMAP 2017). Retrieved from http://creativecommons.org/licenses/by-nc/4.0/

[67] Symeou, L. (2009). Parental involvement in schools: The perspectives of Cypriot principals. Journal of Education Administration and Policy Studies, 1(2), 28-35.

[68] Şad, N. (2012). Investigation of parental involvement tasks as predictors of primary students' Turkish, math and science \& technology achievement. Eğitim Araştırmaları, 49, 173-196.
[69] Sad, S.N. \& Gürbüztürk, O. (2013). İlköğretim birinci kademe öğrenci velilerinin çocuklarının eğitimine katılım düzeyleri [Primary school students' parents' level of involvement into their children's education]. Educational Sciences: Theory \& Practice, 13(2), 1006-1011.

[70] Tomlinson, H. B. \& Andina, S. (2015). Parenting education in Indonesia: Review recommendations to strengthen programs and systems. World Bank Group. Retrieved from http://documents.worldbank.org/curated/en/9125014680017 57855/pdf/97936-PUB-Box39149 8B-PUBLIC.pdf

[71] The Ministry of Education Head Council of Education and Morality [MEB TTKB]. (2005). İlköğretim 1-5. sinıf programları tanitım el kitab1. [An introduction guide of the 1st-5th primary school curriculum], Ankara: Devlet Kitapları Müdürlüğü Basım Evi.

[72] The Ministry of Education Head Council of Education and Morality [MEB TTKB]. (2008). Öğrenciyi ve program. anlamaya yardımcı ilkögretim veli kılavuzu. [A parental guide to help understanding the curriculum and the students], Ankara: Talim ve Terbiye Kurulu Başkanlığı.

[73] The Ministry of Education General Directorate of Teacher Training and Education [MEB ÖYEGM] (2006). Temel eğitime destek projesi öğretmen eğitimi bileşeni: Öğretmenlik mesleği genel yeterlikleri. [The general competencies of teaching profession], Tebliğler Dergisi, 69 (2590).

[74] The Ministry of National Education [MEB]. (2012). Millî eğitim bakanlığ 1 okul-aile birliği yönetmeliği. [The regulation on school-parents association of The Ministry of National Education], Retrieved from http://www.meb.gov.tr $/$ mevzuat/liste. asp?ara $=7$.

[75] The Parent Institute (2014). 5 great ways schools can use social media to engage parents \& families. Retrieved from www.parent-institute.com

[76] Tiryakioğlu, F. \& Erzurum, F. (2011). Bir eğitim aracı olarak ağların kullanımı. [The usage of social networks as an educational tool], $2^{\text {nd }}$ International Conference on New Trends in Education and Their Implications. 27-29 April, Antalya-Turkey. 1031-1047.

[77] Turkish Republic Ministry of European Union (2016). Fas1l 26-Eğitim ve Kültür. [Part 26- Education and Culture], online available from http://www.ab.gov.tr/ nindex.php

[78] Turkish Republic Ministry of Development (2016). Onuncu Kalkınma Planı (2014-2018). [The Tenth Development Plan], online available from

http://www.kalkinma.gov.tr/Lists/Kalknma\%20Planlar/Atta chments/12/Onuncu\%20Kalk\%C4\%B1 nma\%20Plan\%C4\%B1.pdf.

[79] Turkish Republic Lifelong Learning General Directorate (2016). Aile Eğitimi Programı 0-18 yaş uygulamaları2014/17 sayıl1 genelge. [The parental education programmeApplications between 0-18 years old], online available from http://aileegitimi.meb.gov.tr/index.php

[80] UNICEF (2009). Program of support to Syrian education in areas affected by a large influx of Iraqi Refugee children: Evaluation Report. Retrieved from https://www.unicef.org/evaluation/files/SYRIA_support_ed ucation MENA.pdf. 
[81] Ünal, A., Yıldırım, A. \& Çelik, M. (2010). İlköğretim okulu müdür ve öğretmenlerinin velilere ilişkin algılarının analizi. [An analysiz of perceptions of primary school principals and teachers about parents], Selçuk Üniversitesi Sosyal Bilimler Enstitüsü Dergisi, 23, 261-272.

[82] Varış, F. (1998). Eğitim Bilimine Giriş. [Introduction to educational sciences], İstanbul: Alkım yayıncılık.

[83] Wilder, S. (2014). Effects of parental involvement on academic achievement: A met synthesis. Educational Review, 66, 377-397.

[84] Yaylacı, A. F. (1999). İlköğretim okullarında ailenin okula katılımı (Ankara ili örneği). [The parental involvement in elementary schools- A sample of Ankara state], (Unpublished Master's Thesis), Ankara Üniversitesi Sosyal Bilimler Enstitüsü, Ankara.

[85] Yildırım, A. \& Simsek, H.(2008). Sosyal bilimlerde araştırma yöntemleri. [The research methods in social sciences], Ankara: Seçkin yayınları

[86] Yin, R.K. (2002). Case study research (design and methods). California: Sage Publication.

[87] Zou, W. (2013). A contextual understanding of Mainland Chinese parent involvement in their children's primary school years' education. The Journal of Asian Critical Education, 2, 54-68. 